\title{
Impact of sea ice on the marine iron cycle and phytoplankton productivity
}

\author{
S. Wang ${ }^{1}$, D. Bailey ${ }^{1}$, K. Lindsay ${ }^{1}$, J. K. Moore ${ }^{2}$, and M. Holland ${ }^{1}$ \\ ${ }^{1}$ National Center for Atmospheric Research (NCAR), Boulder, CO, USA \\ ${ }^{2}$ Earth System Science, University of California, Irvine, CA, USA \\ Correspondence to: S. Wang (shanlinw@ucar.edu)
}

Received: 27 December 2013 - Published in Biogeosciences Discuss.: 11 February 2014

Revised: 26 July 2014 - Accepted: 30 July 2014 - Published: 8 September 2014

\begin{abstract}
Iron is a key nutrient for phytoplankton growth in the surface ocean. At high latitudes, the iron cycle is closely related to the dynamics of sea ice. In recent decades, Arctic sea ice cover has been declining rapidly and Antarctic sea ice has exhibited large regional trends. A significant reduction of sea ice in both hemispheres is projected in future climate scenarios. In order to adequately study the effect of sea ice on the polar iron cycle, sea ice bearing iron was incorporated in the Community Earth System Model (CESM). Sea ice acts as a reservoir for iron during winter and releases the trace metal to the surface ocean in spring and summer. Simulated iron concentrations in sea ice generally agree with observations in regions where iron concentrations are relatively low. The maximum iron concentrations simulated in Arctic and Antarctic sea ice are much lower than observed, which is likely due to underestimation of iron inputs to sea ice or missing mechanisms. The largest iron source to sea ice is suspended sediments, contributing fluxes of iron of $2.2 \times 10^{8} \mathrm{~mol} \mathrm{Fe} \mathrm{month}{ }^{-1}$ in the Arctic and $4.1 \times 10^{6} \mathrm{~mol}$ Fe month ${ }^{-1}$ in the Southern Ocean during summer. As a result of the iron flux from ice, iron concentrations increase significantly in the Arctic. Iron released from melting ice increases phytoplankton production in spring and summer and shifts phytoplankton community composition in the Southern Ocean. Results for the period of 1998 to 2007 indicate that a reduction of sea ice in the Southern Ocean will have a negative influence on phytoplankton production. Iron transport by sea ice appears to be an important process bringing iron to the central Arctic. The impact of ice to ocean iron fluxes on marine ecosystems is negligible in the current Arctic Ocean, as iron is not typically the growth-limiting nutrient. However, it may become a more important factor in the
\end{abstract}

future, particularly in the central Arctic, as iron concentrations will decrease with declining sea ice cover and transport.

\section{Introduction}

Sea ice covers a large portion of the high-latitude ocean, and it is very vulnerable to climate change. Arctic sea ice has experienced a large reduction in summer ice extent (Serreze et al., 2007; Kwok et al., 2009), thickness (Rothrock et al., 1999), and multi-year ice cover (Maslanik et al., 2007; Nghiem et al., 2007). Overall the Antarctic sea ice remains relatively unchanged. While there is a mild increase in ice cover (Kurtz and Markus, 2012), there are strong interannual variations in coverage (Oza et al., 2011) and large regional trends (Parkinson and Cavalieri, 2012). Climate projections suggest that sea ice will decline rapidly in future decades in both hemispheres (Holland et al., 2006; Stroeve et al., 2012). Timing of the onset of ice formation and melting will also change (Boe et al., 2009).

Sea ice has strong impacts on ocean biogeochemical cycles and marine ecosystems (Sedwick and DiTullio, 1997; Ducklow et al., 2012). Phytoplankton blooms are often observed in the marginal ice zone, where there is recent melting of sea ice (Smith and Nelson, 1985; Fitch and Moore, 2007). Heavy sea ice cover blocks light and limits phytoplankton growth rates. The seasonal ice-ocean freshwater exchange and brine rejection during ice formation can modify the mixed layer depth and drive vertical mixing, which affects irradiance and nutrient levels experienced by phytoplankton (Stabeno et al., 2010; Taylor et al., 2013). Sea ice removes nutrients from seawater during ice formation, 
intercepts dust deposited on it, and releases nutrients and dust during melting. Therefore, changes in sea ice volume and/or extent will alter the nutrient cycling and the seasonal timing of nutrient availability to phytoplankton.

Iron $(\mathrm{Fe})$ is an essential nutrient for phytoplankton growth. It is required for important biological processes, such as photosynthesis and producing enzymes. The demand for iron and uptake efficiency varies among phytoplankton groups, so that concentrations in seawater also influence the competition between different groups (Wang and Moore, 2011). It is commonly recognized that the Southern Ocean is the largest high-nutrient low-chlorophyll (HNLC) region, and as such primary productivity is often limited by low iron availability (Boyd et al., 2001; Boyd, 2002; Arrigo et al., 2003; Wang and Moore, 2011).

Potential iron sources for high-latitude surface waters include diffusion from sediments (Moore and Braucher, 2008; Tagliabue et al., 2012), sediment resuspension (Planquette et al., 2013), dust deposition (Jickells et al., 2005), snow and sea ice melting (Aguilar-Islas et al., 2008; Lannuzel et al., 2008; Tovar-Sanchez et al., 2010), river input (Klunder et al., 2012), hydrothermal contributions (Tagliabue et al., 2010), glacial runoff (Bhatia et al., 2013) and iceberg melting (Smith et al., 2007; Lin et al., 2011; Shaw et al., 2011). Previous field studies reported that iron concentrations in sea ice can be 1 or 2 orders of magnitude higher than iron concentrations in the underlying seawater (Aguilar-Islas et al., 2008; Lannuzel et al., 2007, 2008; van der Merwe et al., 2011a). In polar regions, dust deposition into seawater is obstructed by the presence of sea ice during winter. Dust deposited on the snow or ice surface accumulates within the ice component (Maenhaut et al., 1996; Sedwick and DiTullio, 1997; Tovar-Sanchez et al., 2010). Suspended sediments can be incorporated into sea ice during formation processes and are then released again during melting (Measures, 1999; Thomas and Dieckmann, 2002). Meanwhile, sediments in sea ice can be transported away from shallow regions by ice movement (Nurnberg et al., 1994; Grotti et al., 2005). Sea ice formation may also remove dissolved iron in surface waters by the process of entrainment in ice itself (Lancelot et al., 2009; Lannuzel et al., 2011). In the Southern Ocean, surface water iron is largely supplied by deep winter mixing. It is then is depleted rapidly by biological uptake and particle scavenging in spring (Tagliabue et al., 2014). Iron from melting ice may be particularly important to marine ecosystems once winter mixing has ceased. Sea ice may therefore constitute a significant iron source at high latitudes, play an important role in controlling the location and timing of iron fluxes to seawater, and regulate phytoplankton production through its impacts on the iron cycle.

The role of sea ice in nutrient cycling has been the subject of an increasing number of studies over the past decade (Aguilar-Islas et al., 2008; de Jong et al., 2013; Lancelot et al., 2009; Lannuzel et al., 2007, 2008, 2011, 2013, 2014; Measures, 1999; van der Merwe et al., 2009, 2011b). Ob- servational data on iron concentrations in sea ice and the surrounding seawater are scarce due to harsh conditions and difficulty in making measurements. Therefore many questions remain regarding the impact of sea ice on the iron cycle. Given the rapid change in Arctic sea ice and the potential for large reductions in ice coverage in both hemispheres in the future, there is an urgent need to explore the role of sea ice in ocean biogeochemical cycles.

Numerical simulations can provide a valuable complement to field measurements in this regard. A previous modeling study conducted by Lancelot et al. (2009) suggests that sea ice-ocean iron exchanges alter the geographic patterns of iron distribution in the Southern Ocean. Simulated annual mean iron uptake in sea ice was on the same order of magnitude as sediment fluxes in the western Ross Sea (Lancelot et al., 2009). The present study constitutes a first attempt to incorporate iron into the sea ice component of the Community Earth System Model (CESM). Multiple sources of iron are incorporated from the perspective of sea ice as a reservoir. Previous measurements in polar regions are reviewed and compared with model results in Sect. 3.1. Impacts of sea ice on the iron cycle and marine ecosystems at high latitudes are examined in Sect. 3.2. Contributions of different sources of iron incorporated into sea ice are analyzed in Sect. 3.3. We next discuss interannual variability of the sea ice and the iron cycle relationships in Sect. 3.4, along with the impacts on phytoplankton. Our conclusions elucidate relationships between future changes of sea ice and iron-limited marine ecosystems.

\section{Methods}

\subsection{The ocean and sea ice components of the CESM}

This work is based on the marine ecosystem and biogeochemistry module of the CESM, which is known as the Biogeochemical Elemental Cycling (BEC) model (Moore et al., 2002, 2004). In this study, we use both active ocean and sea ice components. Atmosphere and land components are set up as data models, which prescribe observation-based forcing information to ocean and ice. The BEC module runs within the ocean physics component of the CESM 1.0, which is the Parallel Ocean Program version 2 (POP2, Smith et al., 2010). The ocean circulation model has a nominal horizontal resolution of 1 degree and 60 vertical levels. The thickness of each vertical level is $10 \mathrm{~m}$ in the upper $150 \mathrm{~m}$ and increases with depth below $150 \mathrm{~m}$. Details of the model as incorporated in the CESM1.0 are described by Danabasoglu et al. (2012). The wind speed-mixing relation in the model was adjusted to better match observed mixed layer depths in the Southern Ocean (de Boyer Montégut et al., 2004).

The sea-ice component in the CESM is the Community Ice CodE version 4 (CICE4) (Hunke and Lipscomb, 2010). CICE4 operates on the ocean horizontal grid. The ice 
model includes elastic-viscous-plastic dynamics, energyconserving thermodynamics, and a subgrid-scale ice thickness distribution (ITD). The ITD includes five categories within each grid cell, which have different thickness, different surface properties, and different melt and growth rates as computed according to the thermodynamics. This version of the CICE model includes a more sophisticated shortwave radiative transfer algorithm and allows for both passive and active tracers (Holland et al., 2012). Though iron is highly reactive, iron speciation, chemical reactions and biological processes in sea ice are not considered in this study. The trace metal is incorporated into CICE4 as a passive tracer. Iron accumulating in sea ice comes from different sources and can be transported by ice motion. Sources of iron to sea ice considered in this study include dust, seawater, and sediment. Detailed description of the iron sources is in Sect. 2.3. Snow on top of sea ice is part of the sea ice component in the CESM. The iron in this snow is included when we refer to iron in sea ice.

\subsection{The biogeochemical model}

The BEC model used here includes four phytoplankton functional groups, one zooplankton group and biogeochemical cycling of multiple growth-limiting nutrients (nitrate, ammonium, phosphate, iron and silicate) (Moore et al., 2004). The four phytoplankton groups are diatoms, diazotrophs, small phytoplankton, and coccolithophores. In the BEC model, the diatom group represents larger phytoplankton, which are less efficient at nutrient uptake and export carbon more efficiently than other phytoplankton types.

The light-, nutrient-, and temperature dependencies of the phytoplankton growth rate are modeled multiplicatively. Phytoplankton growth rates decrease under nutrient stress according to Michaelis-Menten uptake kinetics. Phytoplankton photoadaptation is described by varying chlorophyll to nitrogen ratios based on the model of Geider et al. (1998). Phytoplankton groups also have variable $\mathrm{Fe} / \mathrm{C}$ ratios, which adjust as a function of ambient iron concentrations. Dissolved iron sources to the ocean in the BEC model include atmospheric dust deposition and sediments. There is one "dissolved" iron pool that is assumed to be bioavailable in the BEC model. Iron is removed from the dissolved form by biological uptake and particle scavenging. A fraction of the scavenged iron is assumed lost to the sediment (Moore and Braucher, 2008). Ecosystem parameters were chosen based on field and laboratory data and were described in detail by Moore et al. (2002, 2004). The CESM 1.0 BEC model has been evaluated against observational data sets for the 1990s by Moore et al. (2013). That work also addresses the impacts of 21 st century climate change on marine biogeochemistry and ecosystem dynamics.

\subsection{Modifications related to the iron cycle}

In the previous CESM-BEC model, sea ice acted as a physical barrier for air-sea gas exchange, but had no impact on atmospheric dust deposition. Dust deposition over ice-covered grid cells was released directly into seawater. Accordingly, there was also no iron transfer between sea ice and the ocean.

Both dissolved and particulate iron have been measured within sea ice. Iron concentrations inside the ice can be up to 2 orders higher than the underlying seawater (Aguilar-Islas et al., 2008; Lannuzel et al., 2007, 2008; Measures, 1999; van der Merwe et al., 2011a). Seasonal scenarios of the iron cycle were suggested by Lannuzel et al. (2010). However, the mechanisms for iron sequestration in sea ice and the effects of its release in the marginal ice zone are currently not well constrained. We made several assumptions and simplifications to simulate iron sequestration in sea ice, and then explored the impacts of sea ice on iron fluxes and marine ecosystems.

First, we assumed that the amount of iron removed from seawater during sea ice formation was proportional to the concentration of dissolved $\mathrm{Fe}$ in surface seawater. Instead of pumping iron from the seawater to obtain a fixed concentration of iron in the ice (Lancelot et al., 2009), a constant percentage of iron was removed from seawater and trapped in sea ice. We tested different removal fractions ranging from 50 to $100 \%$ and compared simulated iron concentrations in sea ice with observations. The differences in correlations between simulation and observation were small. A $60 \%$ removal fraction was chosen to provide an optimal match with observations.

Second, additional iron is incorporated into sea ice during ice formation in shallow regions to represent the sedimentary iron input to sea ice reported in previous studies (Measures, 1999; Thomas and Dieckmann, 2002). We assumed that the bioavailable iron incorporated into sea ice from suspended sediment was proportional to iron concentrations in seawater with a spatially varying coefficient, since iron concentrations in shallow regions were mainly controlled by sedimentary input (Moore and Braucher, 2008). The sediment source into sea ice $\left(\mathrm{Fe}_{\text {sed-ice }}\right)$ was computed as $\mathrm{Fe}_{\text {sed-ice }}=$ percSed ${ }^{*} \times \mathrm{dFe}_{\text {water }}$, where $\mathrm{dFe}_{\text {water }}$ represented the simulated iron concentration in surface seawater. percSed* was a spatially varying parameter determined by percSed and a constant coefficient, $f_{\text {sed }}$. The value of percSed, the fraction of sediment area in the model grid cell, was calculated using the high-resolution ocean bathymetry from the ETOPO2 version 2.0 data set (US Dept. of Commerce, 2006). The approach is similar to one developed earlier to estimate the global sedimentary iron source (Moore and Braucher, 2008). To optimize $f_{\text {sed }}$, different values were tested to obtain better correlations between simulated iron concentrations and observational data in sea ice and seawater. Sedimentary iron was only incorporated into sea ice where sediments were shallower than $50 \mathrm{~m}$. Different values 
Table 1. Description of model experiments.

\begin{tabular}{|c|c|c|}
\hline Simulations & Descriptions & $\begin{array}{l}\text { Iron in } \\
\text { sea ice }\end{array}$ \\
\hline CTRL & No iron sequestration in sea ice. & No \\
\hline NOdust & $\begin{array}{l}\text { Dust deposited over ice is } \\
\text { blocked and lost. }\end{array}$ & No \\
\hline FEdust & $\begin{array}{l}\text { Dust deposited over ice is stored in ice } \\
\text { and released during melting. }\end{array}$ & Yes \\
\hline FEsw & $\begin{array}{l}\text { Dissolved iron is transported from seawater } \\
\text { to sea ice during ice formation. } \\
\text { Modifications to FEdust are included. }\end{array}$ & Yes \\
\hline FULL & $\begin{array}{l}\text { Sedimentary iron trapped in sea ice } \\
\text { is considered, as well as } \\
\text { modifications in FEsw. }\end{array}$ & Yes \\
\hline
\end{tabular}

for this depth threshold were tested but a limit of $50 \mathrm{~m} \mathrm{had}$ to be adopted in order to avoid excessive sedimentary iron in the Arctic. However, the sediment injections may be underestimated in wintertime deep-convection regions, and this point will be taken up in a later section.

Sea ice and the overlying snow cover are considered as a barrier and a temporary reservoir for dust in the present work, as it is deposited in specific grid cells of the model. When dust settles over sea-ice-covered regions, it is stored in the ice or snow and passively follows ice mechanical movements. Iron inside the sea ice model component was transported with the ice or snow regardless of its origin. This allows for transport of sedimentary iron from shallow regions to deep, iron-depleted regions. We assumed that there was no chemical removal or biological uptake of iron in sea ice. Furthermore, there was no consideration of trace metal transfer between ice and seawater after ice formation, and iron was only released to seawater upon melting. Iron always remained bioavailable when it was released into the water column. These assumptions include a number of simplifications necessary, in part, due to the lack of sea ice biota in the model.

\subsection{Model experiments}

The initial distributions of nutrients, inorganic carbon and alkalinity were based on the World Ocean Atlas database (Garcia et al., 2006) and the GLODAP database (Key et al., 2004). Dissolved iron was initialized based on the simulations by Moore and Braucher (2008). The atmospheric dust deposition data used in this study were from Mahowald et al. (2005), assuming a dust iron content of $3.5 \%$ and a constant $2 \%$ solubility. The sedimentary iron input data was estimated by Moore and Braucher (2008), based on a highresolution bathymetry and estimated Fe flux constrained by the carbon export.

Atmospheric forcing was taken from the National Center for Environmental Prediction/National Center for Atmospheric Research (NCEP/NCAR) meteorological reanalysis climatology (Kalnay et al., 1996) with a number of modifications (Large and Yeager, 2009). The data set covered the period of 1948 to 2007. Simulations were forced by repeating reanalysis data for 210 years as a spin-up, and then multiple modifications were incorporated. Simulations ran from this state for 30 years, which was long enough so that drifts in upper ocean fluxes declined to negligible levels and marine ecosystems approached steady state. The control simulation (CTRL) was conducted using the original CESM-BEC without any modification.

Four 30-year simulations were conducted following the initial spin-up of 210 years, as summarized in Table 1. All modifications described above were incorporated in the FULL simulation. Impacts of sea ice on the iron cycle and phytoplankton production were evaluated by comparing the FULL simulation with the CTRL simulation. The relative importance of each iron source to sea ice was discussed by comparing several simulations against one another. The differences between the NOdust and the FEdust highlights the contribution of dust to iron accumulation in sea ice. The contribution of seawater iron can be estimated by comparing the FEsw and FEdust. Comparisons between the FULL and the FEsw showed the importance of sediments in ice iron accumulation. Interactions between different iron sources were not considered in the present study.

The iron cycle and marine ecosystems in general are sensitive to the physical climate system. While the CESM generally does a good job of simulating sea ice and ocean physics, there exist certain biases in the model at high latitudes (Danabasoglu et al., 2012; Gent et al., 2011). Physical biases were significantly reduced in our simulations, due to use of the NCEP/NCAR reanalysis climatology data as forcing (Danabasoglu et al., 2014). We focus mainly on comparisons between different experiments conducted in the same physical environment (atmospheric forcings, circulation, sea ice dynamics), in order to discuss the relative importance of iron sources to sea ice and impacts of iron delivered by sea ice on marine ecosystems.

Simulated iron distributions in sea ice and ocean waters are compared with observations in Sect. 3.1. Impacts of sea ice on the iron cycle and marine ecosystems are evaluated by comparing the FULL simulation and the CTRL simulation in Sect. 3.2. We also document the relative importance of different iron sources to sea ice (Sect. 3.3), and examine time-varying impacts of iron sequestration in sea ice from 1998 to 2007 (Sect. 3.4).

\section{Results and discussion}

\subsection{Iron distribution in sea ice and water}

Simulated iron concentrations in surface seawater and sea ice are shown in Fig. 1 for the major bloom periods. Iron concentrations in high-latitude seawater are less well documented than for other regions of the global ocean. There have been only a few studies reporting iron concentrations in sea ice. 
Table 2. Comparison between simulated iron concentrations and observed data $(\mathrm{nM})^{\mathrm{a}}$.

\begin{tabular}{|c|c|c|c|c|}
\hline & Location & Model & Data & Data reference \\
\hline $\begin{array}{l}\text { Surface } \\
\text { Southern } \\
\text { Ocean }\end{array}$ & & 0.15 & $0.14-0.43^{\mathrm{b}}$ & $\begin{array}{l}\text { Moore and Braucher (2008); } \\
\text { Tagliabue et al. }(2012)^{\mathrm{b}}\end{array}$ \\
\hline \multirow[t]{6}{*}{$\begin{array}{l}\text { Antarctic } \\
\text { sea ice }\end{array}$} & $\begin{array}{l}\text { Bellingshausen } \\
\text { Sea }\end{array}$ & $0.25-23.08$ & $1.1-30.2$ & Lannuzel et al. (2010) \\
\hline & East Antarctic & $0.25-0.34$ & $2.64-26.0$ & Lannuzel et al. (2007) \\
\hline & & $0.29-0.41$ & $0.23-14.4$ & van der Merwe et al. (2009, \\
\hline & & $-c$ & $2.11-81.0$ & 2011b, 2011a) \\
\hline & Ross Sea & $-{ }^{c}$ & $1.1-6.0$ & Grotti et al. (2005) \\
\hline & Weddell Sea & $0.08-0.17$ & $0.7-36.8$ & Lannuzel et al. (2008) \\
\hline Surface & Barent Sea & $0.14-0.77$ & $0.6-0.8$ & Klunder et al. (2012) \\
\hline Arctic & Bering Sea & $0.05-4.31$ & $0.9-16.5$ & Nishimura et al. (2012) \\
\hline \multirow[t]{6}{*}{ Ocean } & Bering Sea & $0.28-0.73$ & $0.8-3.14$ & Aguilar-Islas et al. (2008) \\
\hline & Central Arctic & $0.26-1.30$ & $0.5-2.6$ & Klunder et al. (2012) \\
\hline & $\begin{array}{l}\text { Canada Basin, } \\
\text { Chukchi Sea }\end{array}$ & $0.25-4.10$ & $0.5-3.18$ & Nakayama et al. (2011) \\
\hline & Chukchi Sea & $0.37-.80$ & $2.1-16.3$ & Nishimura et al. (2012) \\
\hline & Fram Strait & 0.16 & $5.7-23.1$ & Tovar-Sanchez et al. (2010) \\
\hline & Laptev Sea & $0.07-3.77$ & $0.3-10.5$ & Klunder et al. (2012) \\
\hline $\begin{array}{l}\text { Arctic } \\
\text { sea ice }\end{array}$ & Bering Sea & $9.5-61$ & $2.92-376$ & Aguilar-Islas et al. (2008) \\
\hline
\end{tabular}

${ }^{a}$ Model data show simulated iron concentrations from the locations of measurements, except the surface dFe concentrations in the Southern Ocean, which show mean concentrations. ${ }^{b}$ Moore and Braucher (2008) and Tagliabue et al. (2012) have thoroughly compiled observations of iron in the Southern Ocean waters. Detailed comparison between simulated and observed iron concentration in the Southern Ocean seawater can be found in Moore and Braucher (2008). ${ }^{\mathrm{c}}$ The location is not simulated in the 1degree CESM due to the coarse resolution.

Here we first review the observations, then compare model results with observed iron concentrations in seawater and sea ice, respectively, in the Southern Ocean. We then move on to analyze the simulated results against observations available in the Arctic Ocean.

Measurements of dissolved iron $(\mathrm{dFe})$ in the Southern Ocean seawater have been compiled in previous studies (Moore and Braucher, 2008; Tagliabue et al., 2012). Mean observed dFe concentrations are in the range of $0.14-0.5 \mathrm{nM}$, with lower values in the sub-Antarctic regions and higher concentrations representative of the shelf and shallow areas (Moore and Braucher, 2008; Tagliabue et al., 2012). The model does a good job of capturing the general pattern of iron distributions and the magnitudes reported in field studies, with the highest iron concentrations in surface waters around the Antarctic Peninsula (Fig. 1). Simulated seawater iron concentrations and observational data are compared in detail in Moore and Braucher (2008).

Observed iron concentrations in Antarctic pack ice vary considerably: $0.23-26 \mathrm{nM}$ in the East Antarctic (Lannuzel et al., 2007; van der Merwe et al., 2009, 2011a, b), 0.7-36.8 nM in the Weddell Sea (Lannuzel et al., 2008), and 1.1-30.2 nM in the Bellingshausen Sea (Lannuzel et al., 2010). Samples of sea ice in the Ross Sea have lower iron concentrations: 1.1-
$6.0 \mathrm{nM}$ (Grotti et al., 2005). Iron in sea ice is replenished in winter and then decreases as summer progresses (Lannuzel et al., 2010).

Comparisons between simulated and observed iron in sea ice are shown in Table 2. In our simulations, $\mathrm{dFe}$ concentrations in Antarctic sea ice are generally lower than $2 \mathrm{nM}$, except near the Antarctic Peninsula. The low bias in our results is likely due to underestimation of iron inputs or the omission of other mechanisms. Sedimentary iron is only incorporated into sea ice where the water column is shallower than $50 \mathrm{~m}$ in our simulation. However, ocean bathymetry is often deeper than $50 \mathrm{~m}$ in the ocean model grid. This parameterization may cause an underestimate of entrainment of suspended sediments. In regions such as the Ross Sea, where deep convection occurs during winter, sediments may be brought up by the deep mixing. It is also possible that certain mechanisms for incorporation of iron into sea ice are missing from our simulations. Iron can be incorporated into sea ice with detrital and living organisms during ice formation and then degraded into dissolved $\mathrm{Fe}$ via heterotrophic processes (Lannuzel et al., 2010). Iron may also be continuously transferred from seawater into sea ice due to active biological uptake by ice algae (Lannuzel et al., 2010). These mechanisms are ignored in our study, but could be included 


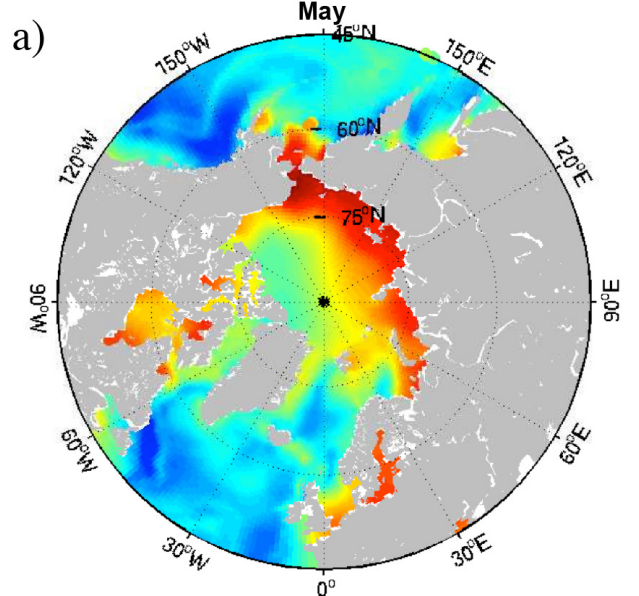

c)

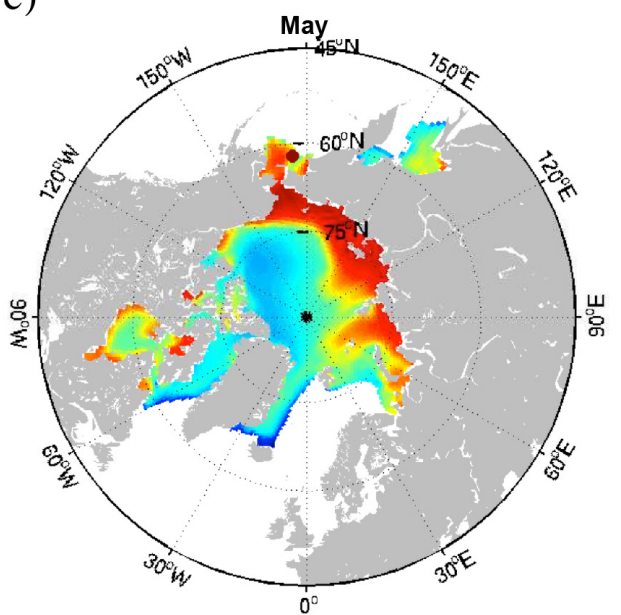

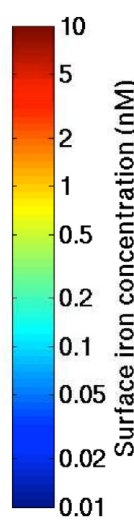

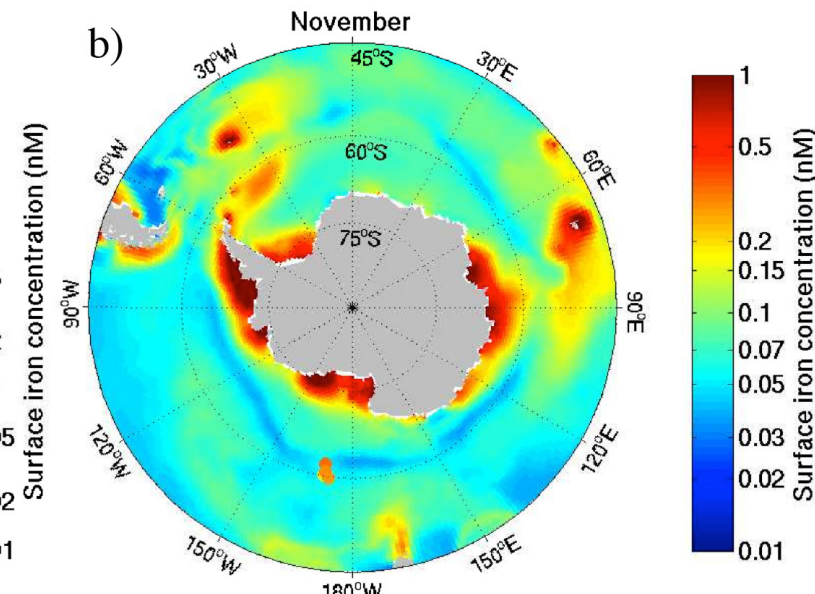

d)

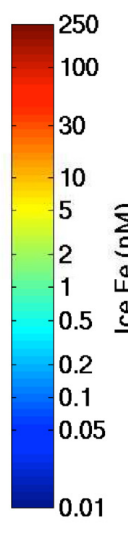

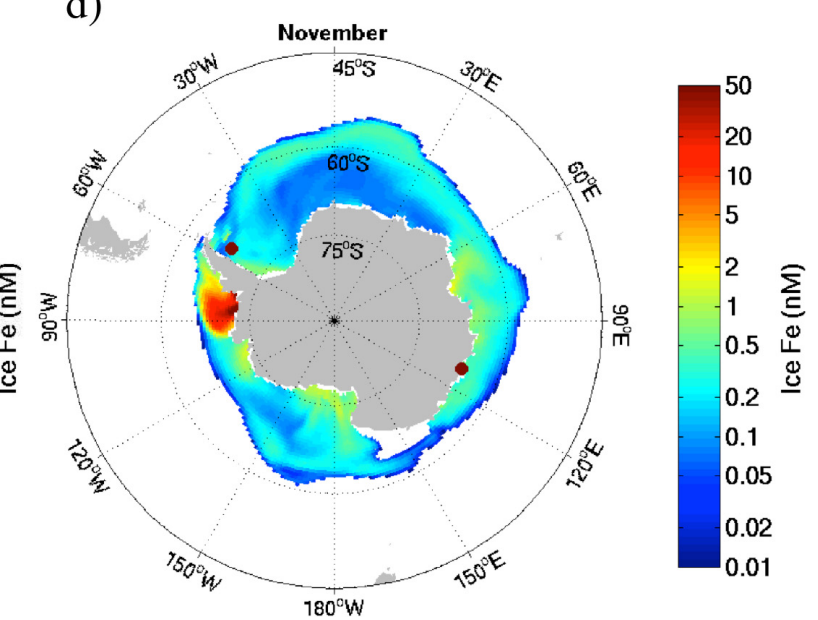

Figure 1. Simulated iron concentrations in $(\mathbf{a}, \mathbf{b})$ seawater and $(\mathbf{c}, \mathbf{d})$ sea ice in $(\mathbf{a}, \mathbf{c})$ the Arctic and (b, d) the Antarctic. Results are iron concentrations in May in the Arctic and November in the Antarctic, when phytoplankton biomass starts increasing rapidly. The color scale is logarithmic. (c, d) show data where ice concentration is greater than $15 \%$ in simulations. Observations are scattered over the model fields.

in future work. This may cause some biases in our simulations. Simulated iron concentrations in sea ice above shallow water near the West Antarctic Peninsula are up to $134 \mathrm{nM}$ during late winter months. This is higher than reported $\mathrm{dFe}$ concentrations in Antarctic sea ice. However, simulated dFe concentrations in sea ice in the Bellingshausen Sea in spring and summer months are lower than $24 \mathrm{nM}$, which agree with previous observations (Lannuzel et al., 2010). Simulated dFe concentrations are higher in sea ice near the continental shelf and decline offshore. There are elevated $\mathrm{dFe}$ concentrations along the margin of sea ice, especially on the east side of the Antarctic Peninsula. This is likely attributable to the flow of sea ice, which transports iron-rich sea ice formed near the Antarctic Peninsula downstream. Iron concentrations are higher during winter and decrease rapidly in November and December, which agree with the seasonal variation shown in observations.

In the Arctic region, in situ studies have reported high dissolved iron concentrations in the Laptev Sea, the Fram Strait, the Bering Strait, and the Chukchi Sea: values are $>10 \mathrm{nM}$ (Klunder et al., 2012), 5.7-23.1 nM (Tovar-Sanchez et al., 2010), 5-10 nM (Nishimura et al., 2012), and 2.1-16.3 nM (Nishimura et al., 2012), respectively. Lower concentrations are observed in other Arctic regions. Klunder et al. (2012) reported that surface $\mathrm{dFe}$ concentrations in the central Arctic were in the range of 0.5 to $>2 \mathrm{nM}$. Iron concentrations in the Canada Basin and the Chukchi Sea are 0.5-3.2 nM in September 2008 (Nakayama et al., 2011). Aguilar-Islas et al. (2008) reported iron concentrations in the Bering Sea of between $0.8-3.14 \mathrm{nM}$ in spring/summer 2007. Surface $\mathrm{dFe}$ concentrations in the Siberian shelf seas (Barents Sea and Kara Sea) are relatively low during August and September $(<1 \mathrm{nM})$ (Klunder et al., 2012). Comparisons between model output and observational data are shown in Table 2. By comparison with the CTRL simulation, simulated surface iron distributions in the FULL experiment are improved in the central Arctic, the Bering Strait, the Chukchi Sea, and the Canada Basin. The FULL simulation overestimates iron 
concentrations in offshore areas of the Barents Sea and Kara Sea. A previous study suggested that the depletion of iron in the Barents Sea and Kara Sea is caused by biological uptake (Klunder et al., 2012), however, simulated phytoplankton biomass in CESM1.0 is biased low in this region (Moore et al., 2013). Weak biological uptake in the model likely contributes to a general overestimation of iron concentrations. Simulated iron levels along the Fram Strait are similar in the CTRL and FULL experiment, and biased low compared to observations. This is likely due to positive biases in biological production and the large consumption of iron by phytoplankton in this region. The general pattern of iron distributions in our experiment agrees well with observations, except for this Fram Strait region.

Observations of iron concentrations in Arctic sea ice are scarce. Aguilar-Islas et al. (2008) reported that dFe concentrations in sea ice in the Bering Sea varied from 2.92 to $376 \mathrm{nM}$, with a geometric mean of $22.9 \mathrm{nM}$. Simulated dFe stocks fall in this range of observations. The highest simulated dFe concentrations in April, May and June are $119 \mathrm{nM}$, $159 \mathrm{nM}$ and $192 \mathrm{nM}$ in the Bering Strait and Chukchi Sea.

Iron sequestration in sea ice has been considered in a previous modeling study of iron sources in the Southern Ocean, by Lancelot et al. (2009). Compared to the results of Lancelot et al. (2009), simulated iron concentrations in Antarctic sea ice are generally lower in our work, except along the West Antarctic Peninsula. This is mainly due to different parameterizations for the transfer of ocean $\mathrm{dFe}$ to sea ice. Lancelot et al. (2009) set a maximum iron concentration of $16.5 \mathrm{nM}$ in sea ice and transferred iron from seawater to ice to ensure this value. The parameterization caused extremely low $\mathrm{dFe}$ concentrations in seawater and relatively high iron stocks in sea ice. In the simulations here, a fixed fraction of iron is removed from seawater to ice during ice formation, ensuring a reasonable amount of $\mathrm{dFe}$ remains in the water. However, it must be stated that there are no strong observational constraints on the fraction of $\mathrm{dFe}$ incorporated into the sea ice during ice formation.

\subsection{Impacts of sea ice on the iron cycle and marine ecosystems}

Differences of net iron fluxes to the surface ocean between the CTRL and the FULL simulations (FULL - CTRL) are shown in Fig. 2a. There is a relative negative influx of iron to the surface ocean in the FULL experiment in ice-forming areas. There are two reasons for the differences. First, sea ice in the modified model blocks the dust deposition, which causes a decrease in the net iron supply to seawater compared to the CTRL simulation. Second, a fraction of the iron is incorporated into sea ice during ice growth, which leads to a negative iron flux from ice to seawater. When melting takes place, both dust and iron in the ice are released to the seawater. Suspended sediments trapped in ice are also released to the seawater as "new" iron available for phytoplankton growth, during spring/summer when there are more light and macronutrients available in the mixed layer. Compared to the CTRL, the iron input during the melting season shifts northward in the Southern Ocean, and in the Northern Hemisphere toward the Bering Sea, the Fram Strait, and the west Arctic.

Impacts of sea ice on the iron concentrations in seawater and marine ecosystems depend strongly on the factors limiting phytoplankton growth. Increased iron input can stimulate phytoplankton production if iron is the most limiting factor for growth. However, iron concentrations in seawater may not change significantly due to rapid biological uptake. When phytoplankton are not limited by iron, iron concentrations in seawater will increase with increased iron input.

Primary production in the Arctic is limited mainly by light and macronutrient concentrations, except for some areas in the Bering Sea and the Sea of Okhotsk (Moore et al., 2013). Thus ambient iron concentrations increase with larger inputs. Ice melting in spring causes large concentration increases in Arctic surface waters (Fig. 2b). The greatest rise appears in the east Arctic, where there is wide shallow continental shelf. The impact of ice on surface iron distributions is generally confined in the seasonal ice zone. Only a small amount of iron is laterally transported by sea ice to the Barents Sea and the south Bering Sea.

Figure 2a shows clear changes of the total iron input to seawater in the Southern Ocean. Previous studies reported that melting ice released $0.30-0.70 \mu \mathrm{mol} \mathrm{Fe} \mathrm{m}^{-2} \mathrm{day}^{-1}$ of iron to surface waters in the East Antarctic, the Weddell Sea, and the Ross Sea (Lannuzel et al., 2007, 2008; de Jong et al., 2013). Simulated iron fluxes from sea ice to ocean are often less than $1 \mu \mathrm{mol} \mathrm{Fe} \mathrm{m}{ }^{-2}$ month $^{-1}$ in the Southern Ocean in our simulations, except in the Bellingshausen Sea $\left(>30 \mu \mathrm{mol} \mathrm{Fe} \mathrm{m}{ }^{-2}\right.$ month $^{-1}$ ). The flux is lowest in the Australian sector of the Southern Ocean. Simulated iron supply from sea ice in the Ross Sea is $4.9 \mu \mathrm{mol} \mathrm{Fe} \mathrm{m}{ }^{-2}$ month $^{-1}$ during the growth season and totals $14.7 \mu \mathrm{mol} \mathrm{Fe} \mathrm{m}{ }^{-2}$ "new" iron annually, which is 1 order of magnitude smaller than previous estimates compiled by Boyd et al. (2012). The model fluxes are lower than the observational studies, but are averaged over an entire model grid cell and over monthly timescales. The local-scale, daily release would be higher in regions where ice was melting. The pattern of iron supply from sea ice is quite different from results in the previous study of Lancelot et al. (2009), due to the varying parameterizations of iron incorporation. In the previous study, the iron flux is highest in the Weddell Sea and East Antarctic and quite low in the Amundsen-Bellingshausen Sea $\left(<0.25 \mu \mathrm{mol} \mathrm{Fe} \mathrm{m}{ }^{-2}\right.$ month $^{-1}$, Lancelot et al., 2009). Our simulated iron fluxes between sea ice and ocean during summer are about 1 order of magnitude smaller than estimates by Lancelot et al. (2009) in the Weddell Sea and East Antarctic regions. In both the study of Lancelot et al. (2009) and this study, concentrations in seawater show no significant changes after coupling the iron cycle to sea ice (Fig. 2b), because iron is often the strongest limiting factor 
a)
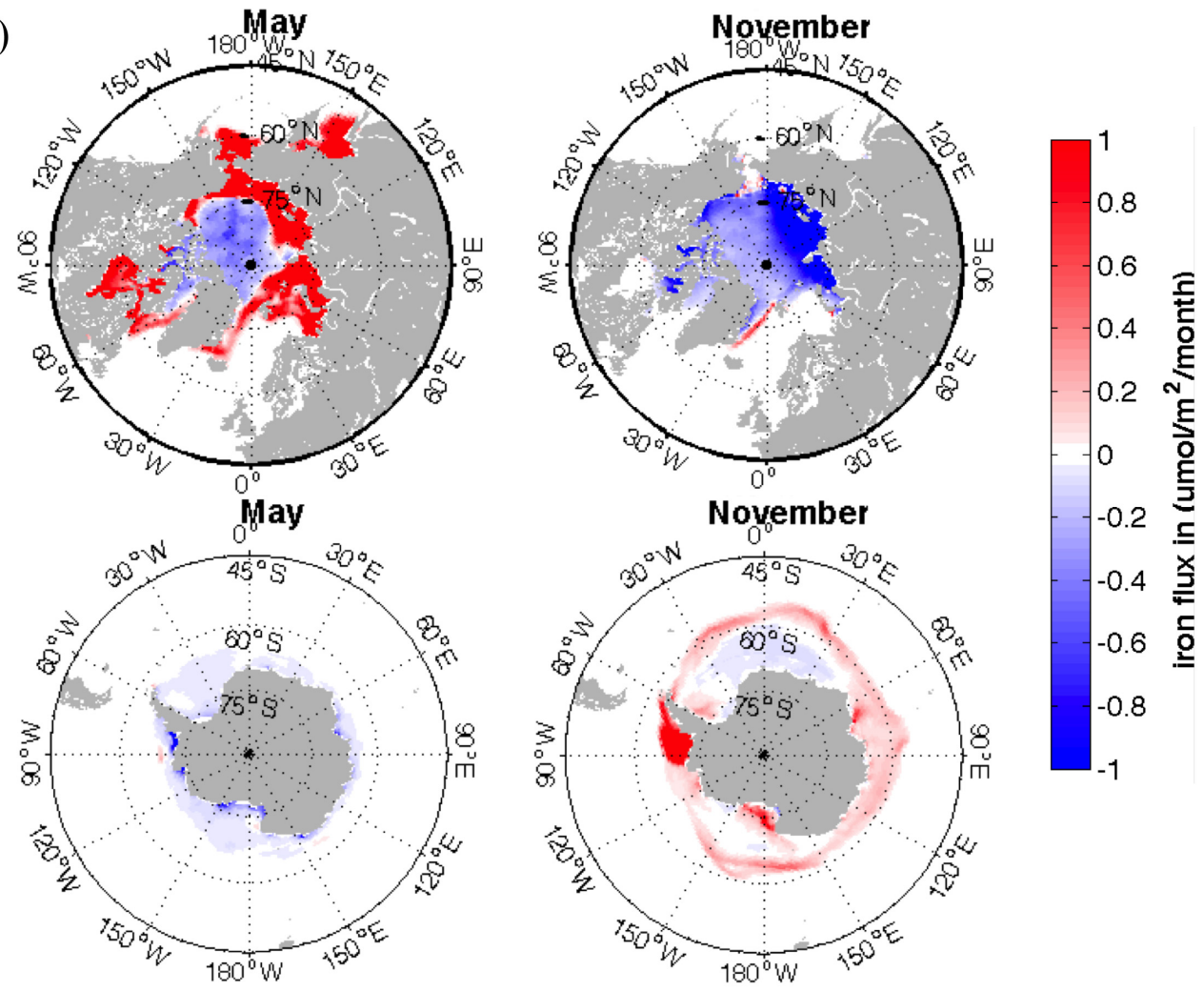

b)
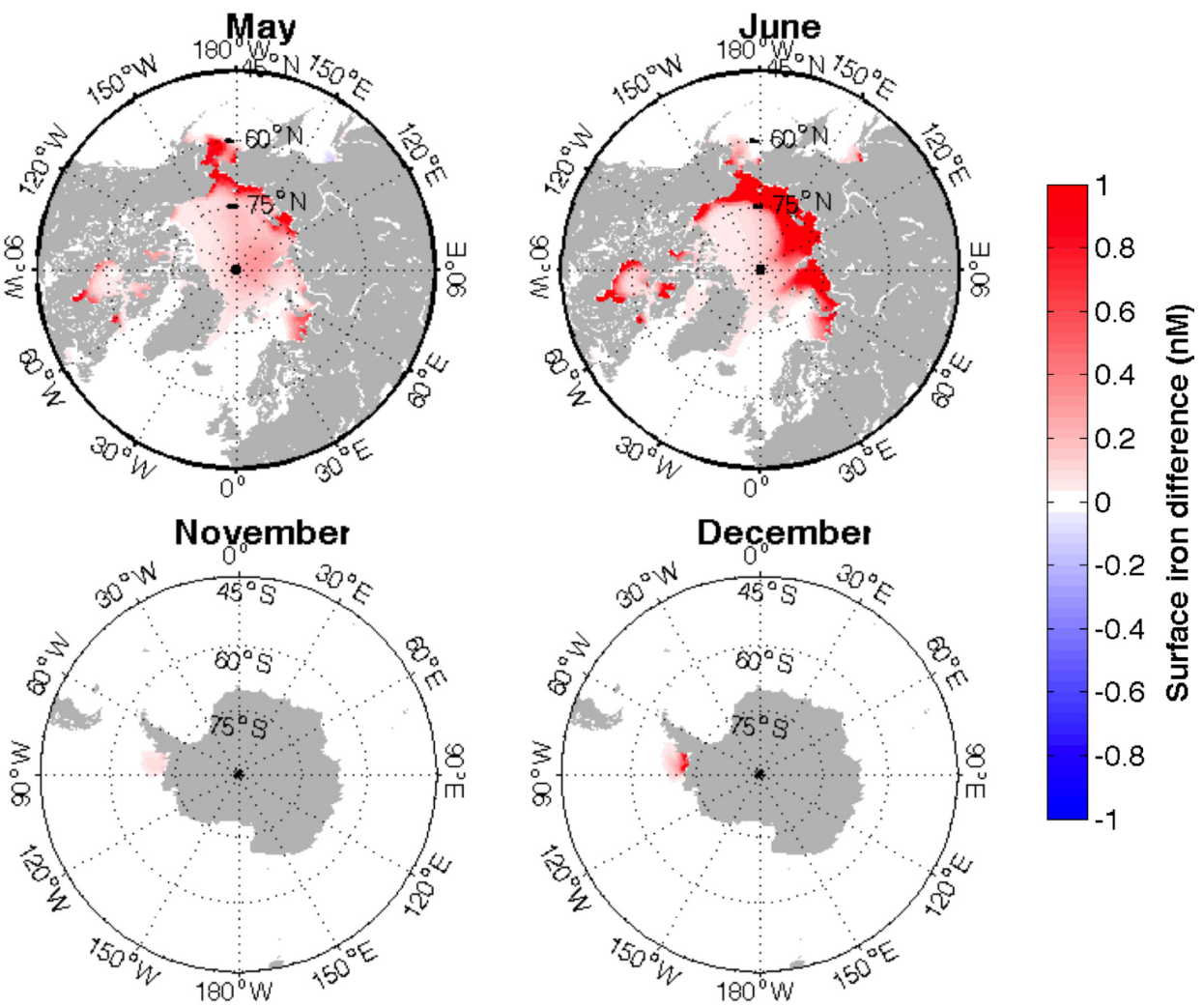

Figure 2. Differences between the CTRL and the FULL simulations (FULL - CTRL): (a) the net iron flux to the surface ocean in May and November. Negative values indicate iron primarily removed from seawater due to ice formation. Positive values indicate enhanced iron input to the surface ocean due to effects of sea ice. (b) Mean surface iron concentrations during the growing season. 

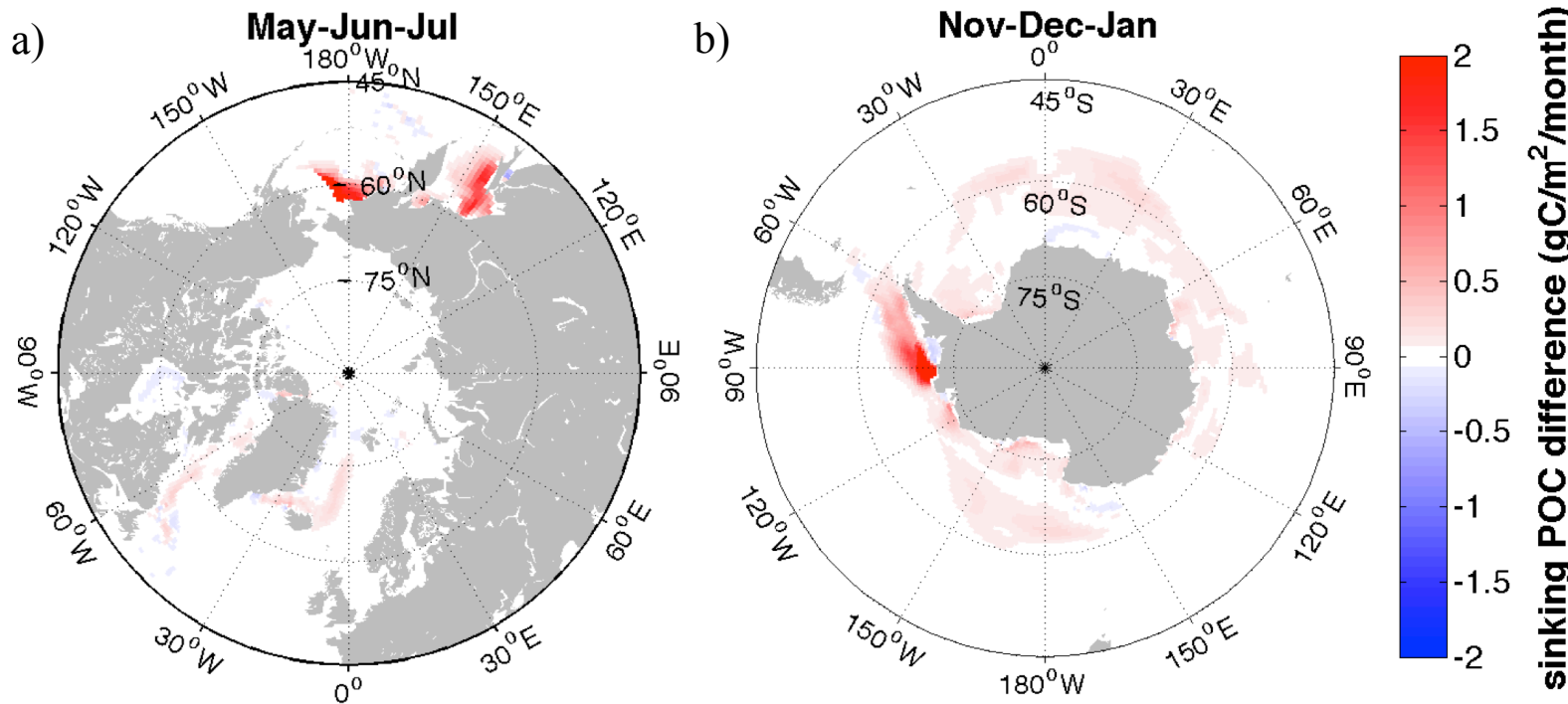

Figure 3. Impacts of iron supply from sea ice on export production during growing season: (a) May, June, and July in the Northern Hemisphere; (b) November, December, and January in the Southern Hemisphere. The figure shows differences of export production between the FULL and the CTRL simulations.

for phytoplankton growth in the Southern Ocean (Arrigo et al., 2003; Boyd, 2002; Moore et al., 2004; Wang and Moore, 2011). Thus, iron from melting ice is rapidly consumed by phytoplankton.

Due to the sequestration process, iron is enriched in sea ice in winter and then released into seawater in spring and summer at a time ideal for phytoplankton growth because the light availability and stratification of the water column are optimum. As a result, biological production increases in both hemispheres. Differences in export production during the growing season are shown in Fig. 3. In the Arctic region, simulated export production is mostly unchanged, except in the Bering Sea and the Sea of Okhotsk. This is because limitation is mainly due to light and other nutrients (Moore et al., 2013). Aguilar-Islas et al. (2008) found strong evidence for the ice-iron linkage leading to phytoplankton blooms in the Bering Sea. Export production in spring and summer is generally enhanced by iron supply from ice in the Southern Ocean. This agrees with previous field studies, which suggest that iron released by sea ice melting fuels summer blooms in the Southern Ocean (Sedwick and DiTullio, 1997; Tagliabue and Arrigo, 2006). Overall, the effects of ice-released iron on biological production are moderate. Changes of surface phytoplankton carbon biomass due to iron flux from sea ice in regions south of $60^{\circ} \mathrm{S}$ are in the range of -0.01 to $0.52 \mathrm{mmol} \mathrm{m}^{-3}$. Overall export production increases less than $4 \%$ in the growing season.

Sea ice shifts the timing and location of iron supplied to high-latitude surface waters. The various phytoplankton groups included in BEC show different responses to melting ice (Fig. 4). Small phytoplankton biomass increases rapidly along the margins of sea ice in spring. Elevated production of diatoms only appears near the West Antarctic Peninsula in November, where iron concentrations in sea ice are highest. During December, average small phytoplankton biomass between $60-70^{\circ} \mathrm{S}$ increased from $0.14 \mu \mathrm{M}$ to $0.16 \mu \mathrm{M}$. Increases in small phytoplankton biomass are mostly confined to the range $60-65^{\circ} \mathrm{S}$. By contrast, diatom biomass increases at higher latitudes. This is because diatoms are more abundant in nearshore waters and require higher iron supply for growth (Wang and Moore, 2011). Changes in percentages of phytoplankton carbon biomass are less than $10 \%$ in most regions. Simulated dominance patterns display no significant changes - diatoms continue to dominate coastal, iron-rich water masses and small phytoplankton prevail in the open sea. The simulated small phytoplankton and diatom groups also have different responses to the iron supply from sea ice in the Northern Hemisphere (not shown). There is an increase of diatom biomass in the Bering Sea and the Sea of Okhotsk in spring, while small phytoplankton biomass remains similar with only a slight decrease in the south Bering Sea in June. The supply of iron therefore shows a modest impact on phytoplankton community structure. Arrigo et al. (2008) suggest that Arctic phytoplankton production may rise to 3 times the current level. Such a large increase in phytoplankton biomass would consume a large amount of iron and could cause a shift toward iron limitation. In this case, sea ice may become a more important source for bioavailable iron in the Arctic as well.

\subsection{Iron sources to sea ice}

Three sources of iron are considered for iron accumulation in sea ice: atmospheric deposition, seawater iron, and 
a)

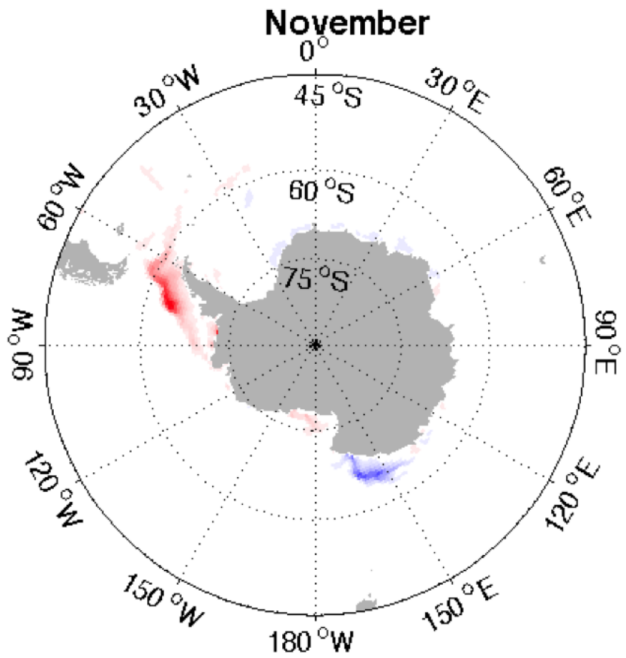

b)

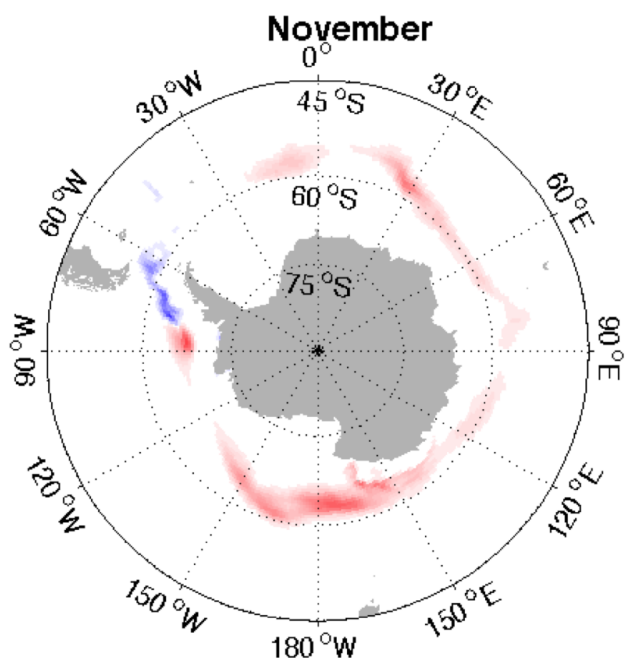

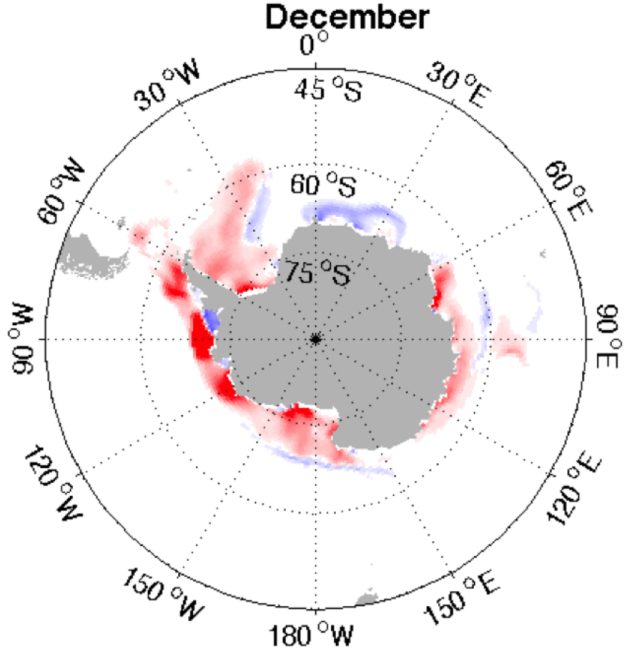

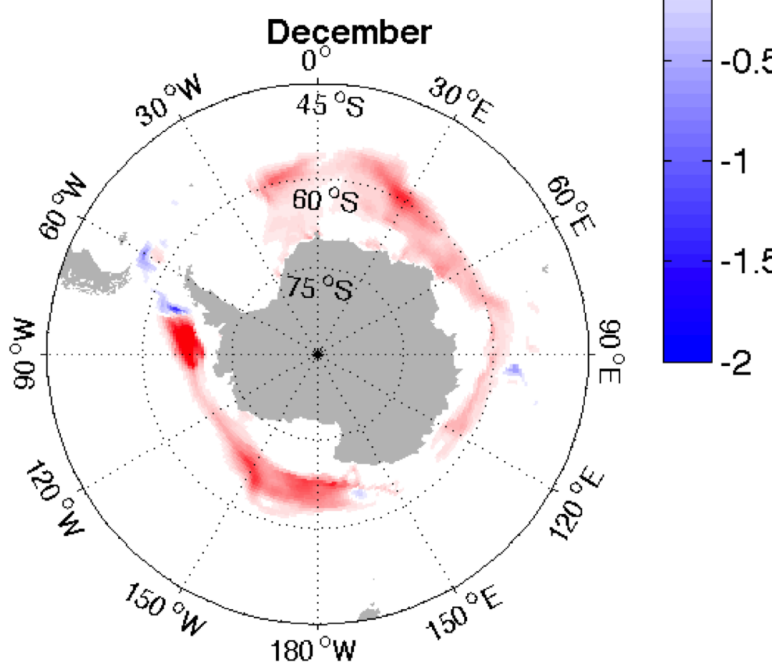

Figure 4. Impacts of sea ice on phytoplankton biomass during the growing season in the Southern Ocean: (a) diatoms; (b) small phytoplankton. The figure shows differences of phytoplankton biomass between the FULL and the CTRL simulations.

suspended sediments in shallow regions. Dust iron and sedimentary iron are "new" to the system. Our focus will be on the impacts of iron supply from sea ice to water on phytoplankton production. Model output for summer is analyzed in this section and contributions of different sources of iron incorporated into sea ice are calculated (Fig. 5).

Mineral dust and sedimentary iron contribute roughly equally to dissolved iron on an integrated basis across the global ocean. However, at high latitudes atmospheric deposition is relatively low (Moore and Braucher, 2008). In the Northern Hemisphere, dust deposited on sea ice during winter contributes to $8.5 \times 10^{6} \mathrm{~mol} \mathrm{month}^{-1}$ iron flux to surface seawater in summer. The flux is the highest in the northwest Sea of Okhotsk (Fig. 5a). Dust from Asia depositing onto the top of the pack is stored in ice over the winter and released into surface waters along with melting ice in spring. This delayed release of dust iron causes the enhanced pro- duction discussed in the previous section. The role of dust as an iron source to sea ice is weaker in the high-latitude Southern Ocean. There is an average flux of $2.2 \times 10^{6} \mathrm{~mol}$ dust $\mathrm{Fe}$ month $^{-1}$ from sea ice meltwater (below $45^{\circ} \mathrm{S}$ ). Spatial variation of the flux is relatively low. The total amount of dust iron in sea ice meltwater is less than $1 \%$ of global dust deposited into the oceans. However, dust iron from Southern Ocean sea ice dominates the supply of iron from sea ice to phytoplankton growth in the marginal ice zone.

Iron originally coming from winter seawater contributes to a flux of $1.7 \times 10^{7} \mathrm{~mol} \mathrm{Fe} \mathrm{month}^{-1}$ during the Northern Hemisphere summer. The distribution of the iron flux follows simulated concentrations, higher in the east Arctic and lower in the west (Fig. 5b). The flux is about double that flux contributed by dust. Mean iron flux around the Antarctic attributable to seawater is $1.6 \times 10^{6} \mathrm{~mol} \mathrm{Fe} \mathrm{month}^{-1}$ during summer. Though dust deposition over the seasonal ice 

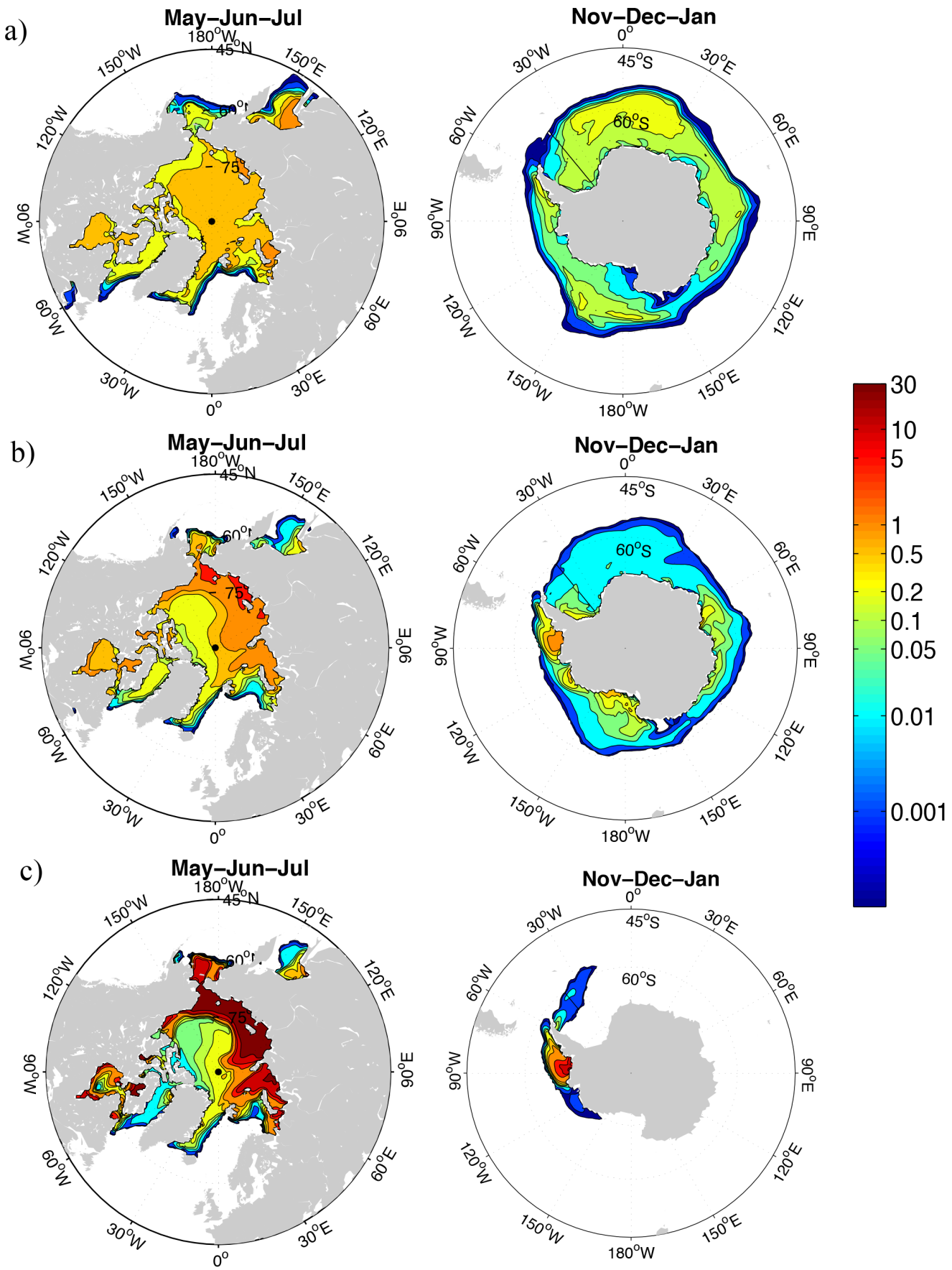

Figure 5. Iron supply from sea ice contributed by different iron sources in summer: (a) dust, (b) seawater, and (c) sediments. Contributions of different iron sources are differences of the net iron flux into the surface ocean (FEdust - NOdust, FEsw - FEdust, and FULL - FEdust, respectively).

zone is low, it is also the case that seawater additions are restricted in the Southern Ocean. This is largely due to iron depletion caused by biological uptake. Iron fluxes contributed by seawater in our study are lower than results of Lancelot et al. (2009), in which iron in surface water is largely transferred to sea ice during the winter, leading to very low con- centrations in seawater. The supply from seawater is higher when ice forms in iron-rich coastal waters. The distribution of fluxes of iron originally from seawater and incorporated into the pack mainly tracks the supply of seawater iron to ice, except in the Ross and Weddell seas where, iron-rich sea ice 
has drifted away from continental areas (Holland and Kwok, 2012).

Incorporation of sediments and their transport offshore are considered for the first time in the present modeling study. Figure 5c shows iron fluxes attributed to sediments in ice. Sediment-laden ice leads to a large iron flux into the ocean in our model. Total sedimentary iron carried by sea ice is equivalent to $\sim 8 \%$ of monthly averaged fluxes from sediment across the global ocean, corresponding to $2.2 \times 10^{8} \mathrm{~mol}$ Fe month ${ }^{-1}$ in the Arctic and $4.1 \times 10^{6}$ mol Fe month $^{-1}$ near the Antarctic in summer. Flux distributions show that iron has been transported from the peripheral Siberian seas toward the central Arctic, which supports the hypothesis that iron may be mobilized by "dirty" sea ice (Measures, 1999; Klunder et al., 2012).

Overall, an additional $8.3 \times 10^{8} \mathrm{~g} \mathrm{Fe} \mathrm{year}^{-1}$ is added to the Southern Ocean $\left(>35^{\circ} \mathrm{S}\right)$ by sediment-bearing ice. This iron supply is smaller than iceberg Fe $\left(1-3 \times 10^{9} \mathrm{~g} \mathrm{Fe} \mathrm{year}^{-1}\right)$, sediment Fe $\left(257-635 \times 10^{9} \mathrm{~g} \mathrm{Fe} \mathrm{year}^{-1}\right)$, hydrothermal Fe $\left(20.8 \times 10^{9} \mathrm{~g} \mathrm{Fe} \mathrm{year}^{-1}\right)$, and dust Fe (4.5$30 \times 10^{9} \mathrm{~g} \mathrm{Fe} \mathrm{year}^{-1}$ ) (summarized by Tagliabue et al., 2010). Boyd et al. (2012) showed that iron flux from melting sea ice is one of the largest iron sources in some regions. Previous studies suggested that iron from melting ice contributed 70-90\% of the total iron supply to surface waters in the East Antarctic, the Weddell Sea, and the Ross Sea during the melting period (Lannuzel et al., 2007, 2008; de Jong et al., 2013). Simulated iron inputs from melting ice in our simulations are generally less than these observational estimates. It is likely the iron supply is underestimated in this study. In the Northern Hemisphere, sediment-bearing sea ice adds $3.9 \times 10^{9} \mathrm{~g} \mathrm{Fe}$ annually to the oceans north of $45^{\circ} \mathrm{N}$, which is more than one time larger than the iron supply from dust $\left(1.8 \times 10^{9} \mathrm{~g} \mathrm{Fe} \mathrm{year}^{-1}\right)$. With the "new" iron from sea ice, simulated iron concentrations agree reasonably well with observations (Table 2).

\subsection{Sensitivity of marine ecosystems to the varying iron supply from sea ice}

Climate models have projected a large reduction in sea ice (Holland et al., 2006; Stroeve et al., 2012). It is necessary to understand the influence of declining sea ice extent and volume on the iron cycle and marine ecosystems in order to estimate the future primary production and the ocean carbon cycle at high latitudes. There has been a significant decrease of Arctic sea ice and large variations in Antarctic sea ice over the past decade. Simulations representing this period provide insight on the sensitivity of iron distributions and phytoplankton production to changes of sea ice extent and volume. We compare differences between the FULL simulation and the CTRL simulation from year to year, focusing on the role of iron released by sea ice. The simulated physical environment is the same in these two simulations. Differences in the biomass of diatoms and small phytoplankton from 1998 to
2007 are shown for the month of December in Fig. 6. These discrepancies are caused by iron-ice interactions. However, variations from year to year are a result of combined effects of the physical environment of surface water and iron fluxes from ice.

Comparing simulations of the Antarctic Peninsula in 2002 and 2004, the mixed layer depths in the Weddell Sea and the Bellingshausen Sea are similar (Fig. 6). The extent of coverage in this region is similar as well, but winter ice volume in 2004 is lower than in the year 2002 (Fig. 7). More iron is removed from seawater and incorporated into sea ice in winter. As a result, there is more iron released in the summer of 2002. Consequently, a large increase of phytoplankton production is simulated in 2002. Differences in the region north of the Amery Ice Shelf between 2000 and 2001 also suggest an important role of ice iron in phytoplankton growth. Iron concentrations are similar for the two years. The larger ice extent in 2000 releases more iron into seawater and causes a clear increase in phytoplankton biomass. Thicker and more extensive ice in the Amundsen Sea in 2001 releases more iron to the surface ocean. This is the reason why there is higher biological productivity in this region during the spring of 2001 , by comparison with succeeding years. Marine ecosystem changes driven by the sea ice iron vary on an interannual basis. For example, anomalies for ice volume, differences of iron concentration and phytoplankton biomass in the Amundsen Sea region are shown in Fig. 7. As expected, iron concentration and ice anomalies are closely related. Positive phytoplankton biomass anomalies are often associated with higher than normal ice volume and vise versa. Comparison of these differences suggests that reduction in sea ice in the future will have a negative effect on biological production that is attributable to the influence of ice on the iron cycle.

Effects of sea ice iron on marine ecosystems are enhanced by the cold and well-illuminated environment created by melting sea ice. Ice melting increases the stratification of surface waters, thus iron from meltwater is often released to areas with a shallow mixed layer. Light is often sufficient for phytoplankton growth in these areas and iron becomes the main limiting factor controlling production. This is why small phytoplankton biomass often shows an immediate increase along the margins, due to enhanced iron fluxes from sea ice (Fig. 6). However, iron fluxes may not be the dominant control on biological production. For example, iron fluxes from ice are similar in the Ross Sea in 2006 and 2007, but the increase of diatom biomass is larger in 2006. The remaining iron in surface water is higher in 2007, which suggests phytoplankton growth is limited by lower light due to the thicker overlying pack ice. Note that the amount of iron released from melting ice is affected by iron concentrations in seawater during the previous autumn, which depends on biological uptake in the growing season. Thus, phytoplankton production from year to year can also be linked through iron sequestration in sea ice. 


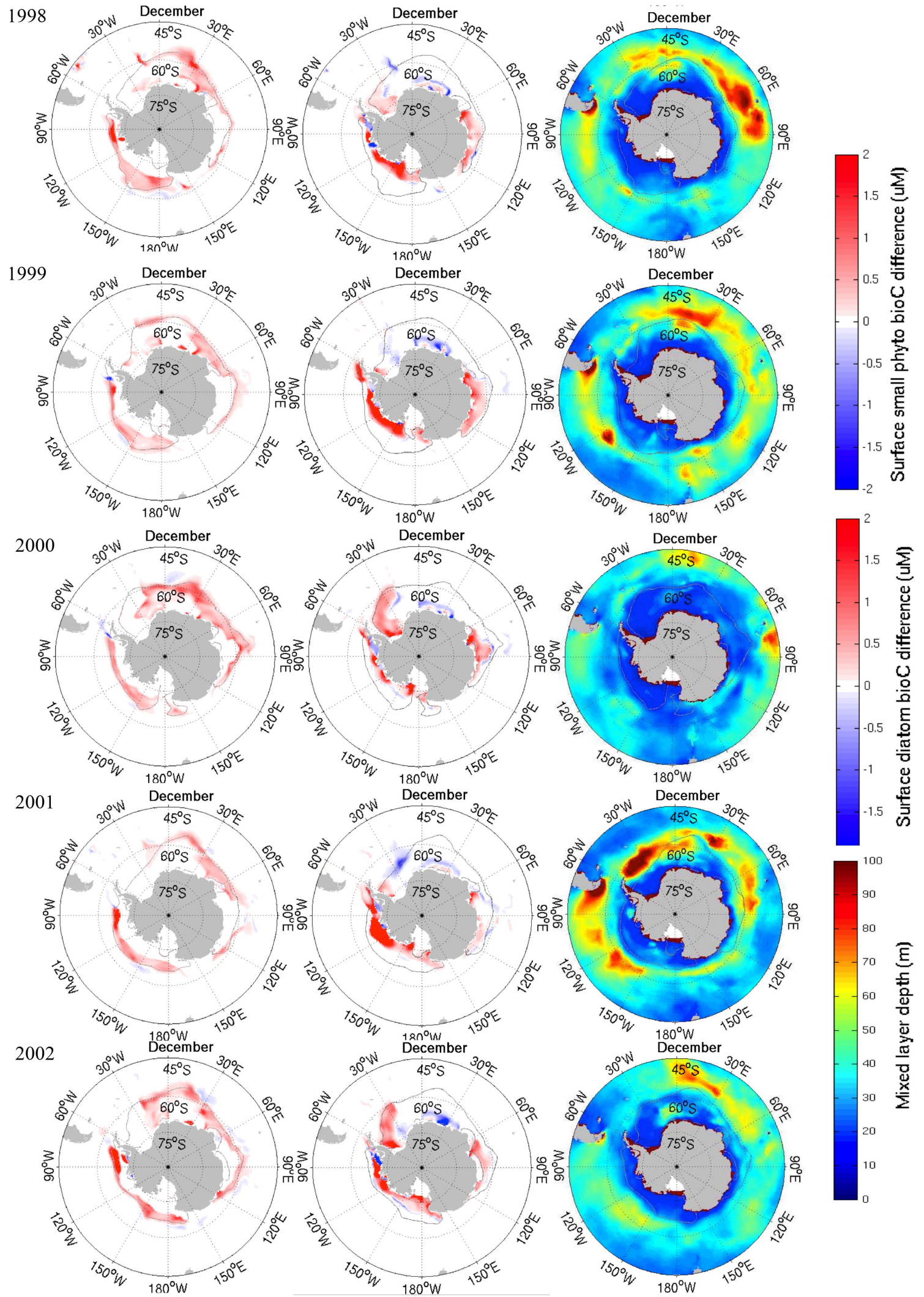

Figure 6. Caption on next page. 


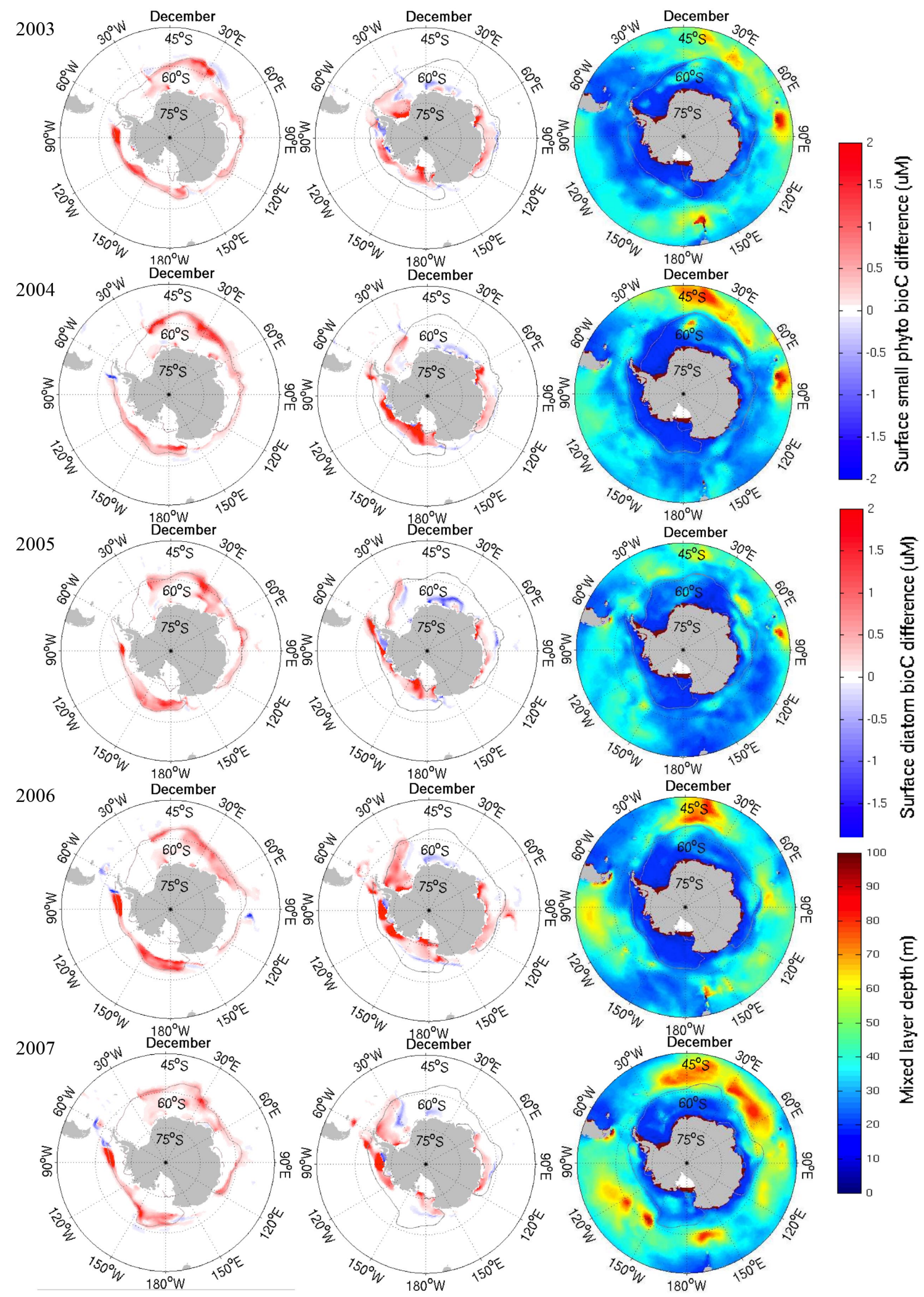

Figure 6. Differences of biomass in December caused by iron fluxes from ice (from 1998 to 2007) (FULL - CTRL): (left) small phytoplankton and (middle) diatoms. The mixed layer depth in December is shown on the right. The grey line shows $15 \%$ ice concentration. 

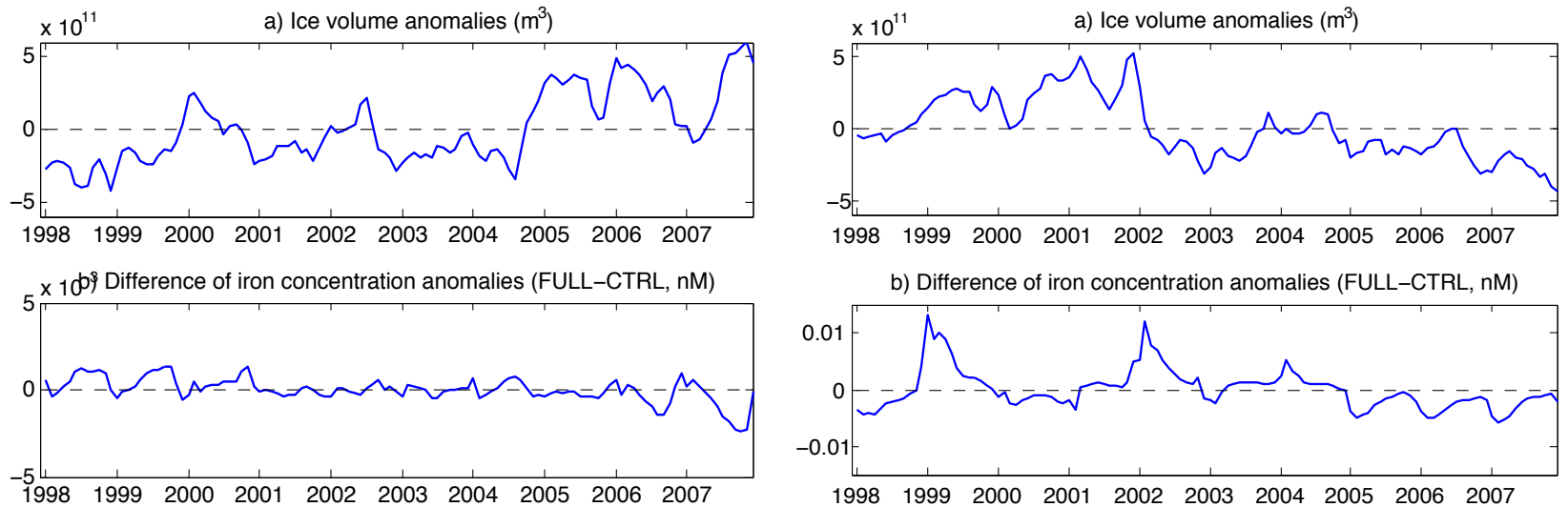

b) Difference of iron concentration anomalies (FULL-CTRL, nM)

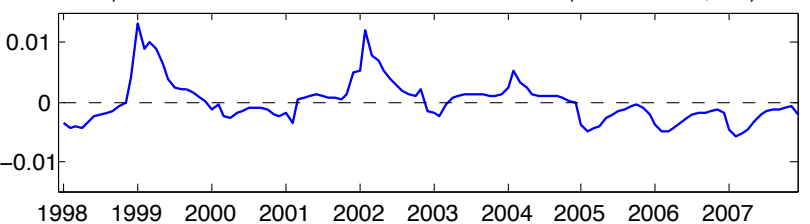

c) Difference of diatom biomass anomalies (FULL-CTRL, $\mathrm{mmol} / \mathrm{m}^{3}$ )

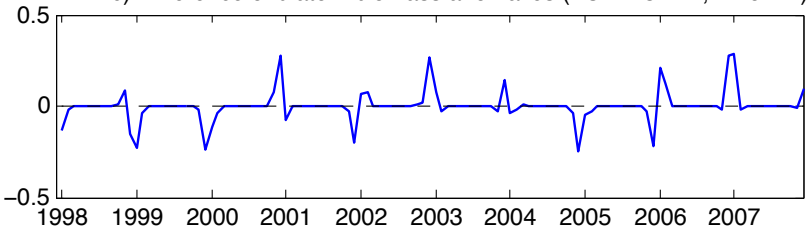

c) Difference of diatom biomass anomalies (FULL-CTRL, $\mathrm{mmol} / \mathrm{m}^{3}$ )

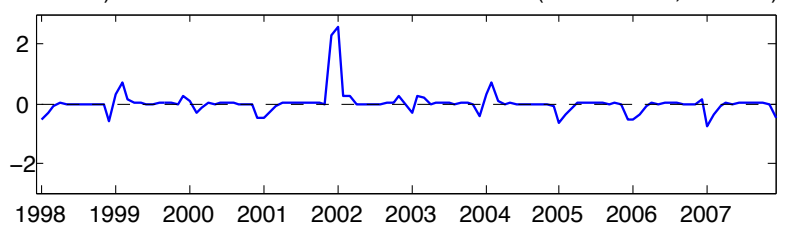

d) Difference of small phyto biomass anomalies (FULL-CTRL, $\mathrm{mmol} / \mathrm{m}^{3}$ )
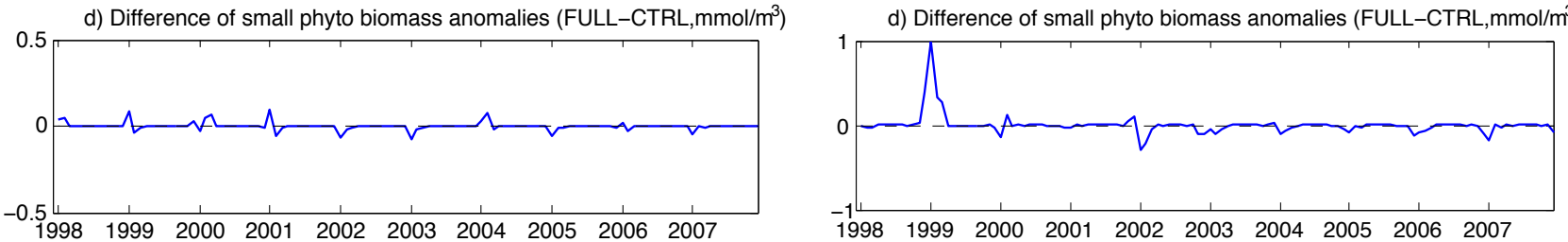

Figure 7. Time series of (left) the Weddell Sea region and (right) the Amundsen Sea region: (a) anomalies of ice volume (i.e., 10-year mean seasonal cycle removed); (b) differences of iron concentration anomalies (FULL - CTRL); (c) differences of diatom biomass anomalies (FULL - CTRL); (d) differences of small phytoplankton biomass anomalies (FULL - CTRL). Differences between the FULL and the CTRL show effects of iron sequestration in sea ice.

Iron sequestration in sea ice also affects the competition between different phytoplankton functional groups. Changes of marine ecosystems in the Atlantic sector of the Southern Ocean offer a clear example of impacts of varying sea ice on phytoplankton community structure (Fig. 6). Sea ice drifts from the Antarctic continent to the north in this region (Holland and Kwok, 2012). When it forms in iron-rich nearshore waters, iron is removed from the water column causing concentration decreases in the surface ocean. Northward sea ice motion then transports the captured iron away from continental areas. As a result, there is a decrease of diatom biomass nearshore, especially during heavy ice years, and an increase of small phytoplankton biomass in the north (Fig. 6). Therefore, increases of sea ice in this region can cause phytoplankton community shifts from diatoms to small phytoplankton.

Increases in iron are generally concurrent with increases of sea ice formation in the Arctic. If the decreasing trend of Arctic sea ice continues, iron concentrations in the Arctic will decline due to lower iron inputs, particularly in the central Arctic. The impacts of iron sequestration in sea ice on marine ecosystems are more complex for simulations between 1998 and 2007. Phytoplankton production is usually limited by light intensity and macronutrient concentrations in the mixed layer (nitrogen and silicon). Though iron is a limiting factor for phytoplankton growth in some areas of the Bering Sea and the Sea of Okhotsk, changes of phytoplankton production are not tightly coupled with iron fluxes from ice. The decoupling between iron fluxes and production occurs when strong ice melting causes a dilution of other nutrients. This is because concentrations of macronutrients in sea ice are usually lower than seawater (Lin et al., 2011; TovarSanchez et al., 2010). Thus, the biogeochemical impacts of melting ice depend on the surrounding ocean environment. Longer simulations forced with future climate conditions are needed if we are to predict the possible impact of iron fluxes from sea ice on marine ecosystems.

\section{Discussion and summary}

Iron sequestration and transport by sea ice are incorporated into the CESM-BEC model to study the role of sea ice in the marine iron cycle, with a full assessment of the impacts on biology. We include suspended sediments as an additional source of iron to sea ice in shallow regions, which can 
advance our understanding of the impacts of "dirty" ice on transport of iron and other materials.

The modified model captures the general patterns of iron distribution and concentrations in the high-latitude oceans. Compared to previous BEC versions, simulated iron concentrations are in better agreement with observations in the central Arctic, the Bering Strait, the Chukchi Sea, and the Canada Basin. Discrepancies in iron concentration are associated with biases in phytoplankton production. Simulated maximum iron concentrations in sea ice are identified in the vicinity of the West Antarctic Peninsula ( $134 \mathrm{nM} \mathrm{dFe})$ and in the Bering Strait and the Chukchi Sea (192 nM dFe). Our simulation cannot reproduce the highest iron concentrations (up to $376 \mathrm{nM} \mathrm{dFe}$ ) observed in the field (Aguilar-Islas et al., 2008). Previous work suggests that the continuous growth of ice algae at the bottom of sea ice during winter also contributes to the accumulation of iron in sea ice (Lannuzel et al., 2010). As such, the model bias may be improved by incorporating an ice algal component to the model (Deal et al., 2011) or by including other biological iron sources in the sea ice. Our assumption of unified iron distributions in each sea ice cell may also be a factor contributing to low iron concentrations. Sea ice microstructure and brine dynamics have strong impacts on tracer distributions in ice (Jeffery et al., 2011; Vancoppenolle et al., 2010). Interactions between iron and brine dynamics should also be considered in future studies. Another caveat in the present work is that iron speciation and related chemical reactions in both seawater and sea ice are not considered. Tagliabue and Arrigo (2006) showed that the cold and well-illuminated environment created by melting sea ice enhanced photochemical activity, which effectively leads to Fe recycling and retention. The impacts of iron released from melting sea ice on marine ecosystems may then be enhanced under such conditions. Chemical reactions should be considered in addition to physical processes in future studies.

Our results show that sea ice can change the timing and location of iron supply to the ocean. Suspended sediments are an important iron source to sea ice and can significantly affect iron distributions in the Arctic. Iron released from sea ice melting enhances phytoplankton production in the Southern Ocean, the Bering Sea and the Sea of Okhotsk. The magnitude of simulated increases in production may be underestimated, because often the observed very high iron concentrations in ice are not reproduced by the model. The simulated influence of ice on phytoplankton agrees with conclusions from previous studies (Measures, 1999; Lannuzel et al., 2008; Sedwick and DiTullio, 1997). The structure of regional-scale ecosystems can be changed by iron from sea ice, because different phytoplankton groups respond differently to iron inputs.

Simulations of 1998 to 2007 show that decreases in sea ice have a negative impact on phytoplankton growth and production, due to interactions with the iron cycle in the Southern Ocean. Iron in sea ice has only a small influence on total phytoplankton production. Iron and some other bioactive metals $(\mathrm{Zn}, \mathrm{Cu}, \mathrm{Ni}, \mathrm{Mn}, \mathrm{Co}, \mathrm{Cd})$ are highly enriched in sea ice (Tovar-Sanchez et al., 2010; Lannuzel et al., 2011), which can be transported by sea ice motion. Given the apparent importance of sea ice mobility in bringing iron to the central Arctic, iron concentrations will likely decrease in the central Arctic as ice coverage continues to decline in the coming decades. Iron limitation of phytoplankton growth rates is possible in a future, ice-free Arctic Ocean during summer months. Declining sea ice cover modifies the light regime experienced by phytoplankton. Ocean circulation, mixed layer depths, and stratification will also be affected. Marine ecosystems are strongly influenced by all of these factors (Arrigo et al., 2008; Lannuzel et al., 2008; Lee et al., 2012; Pabi et al., 2008; Sedwick and DiTullio, 1997). The net physical and biogeochemical effects of sea ice on marine ecosystems need to be considered holistically in the future in the context of the ongoing perturbations of the climate system.

Acknowledgements. This work was supported by the NCAR Advanced Study Program, the National Science Foundation (NSF) Office of Polar Programs, NSF grants OPP-0902068 to Marika Holland, and NSF grants ARC-0902045 and AGS-1048890 to J. Keith Moore. Computational facilities have been provided by the Climate Simulation Laboratory, which is managed by Computational and Information Systems Laboratory at NCAR. NCAR is sponsored by the National Science Foundation.

Edited by: L. Bopp

\section{References}

Aguilar-Islas, A. M., Rember, R. D., Mordy, C. W., and Wu, J.: Sea ice-derived dissolved iron and its potential influence on the spring algal bloom in the Bering Sea, Geophys. Res. Lett., 35, L24601, doi:10.1029/2008g1035736, 2008.

Arrigo, K. R., Worthen, D. L., and Robinson, D. H.: A coupled ocean-ecosystem model of the Ross Sea: 2. Iron regulation of phytoplankton taxonomic variability and primary production, J. Geophys. Res.-Oceans, 108, 3231, doi:10.1029/2001jc000856, 2003.

Arrigo, K. R., van Dijken, G., and Pabi, S.: Impact of a shrinking Arctic ice cover on marine primary production, Geophys. Res. Lett., 35, L19603, doi:10.1029/2008g1035028, 2008.

Bhatia, M. P., Kujawinski, E. B., Das, S. B., Breier, C. F., Henderson, P. B., and Charette, M. A.: Greenland meltwater as a significant and potentially bioavailable source of iron to the ocean, Nat. Geosci., 6, 274-278, 2013.

Boe, J. L., Hall, A., and Qu, X.: September sea-ice cover in the Arctic Ocean projected to vanish by 2100, Nature Geosci., 2, 341343, 2009.

Boyd, P. W.: Environmental factors controlling phytoplankton processes in the Southern Ocean, J. Phycol., 38, 844-861, 2002.

Boyd, P. W., Crossley, A. C., DiTullio, G. R., Griffiths, F. B., Hutchins, D. A., Queguiner, B., Sedwick, P. N., and Trull, T. W.: 
Control of phytoplankton growth by iron supply and irradiance in the subantarctic Southern Ocean: Experimental results from the SAZ Project, J. Geophys. Res.-Oceans, 106, 31573-31583, 2001.

Boyd, P. W., Arrigo, K. R., Strzepek, R., and van Dijken, G. L.: Mapping phytoplankton iron utilization: Insights into Southern Ocean supply mechanisms, J. Geophys. Res, 117, C06009, doi:10.1029/2011jc007726, 2012.

Danabasoglu, G., Bates, S. C., Briegleb, B. P., Jayne, S. R., Jochum, M., Large, W. G., Peacock, S., and Yeager, S. G.: The CCSM4 Ocean Component, J. Climate, 25, 1361-1389, 2012.

Danabasoglu, G., Yeager, S. G., Bailey, D., Behrens, E., Bentsen, M., Bi, D., Biastoch, A., Böning, C., Bozec, A., Canuto, V. M., Cassou, C., Chassignet, E., Coward, A. C., Danilov, S., Diansky, N., Drange, H., Farneti, R., Fernandez, E., Fogli, P. G., Forget, G., Fujii, Y., Griffies, S. M., Gusev, A., Heimbach, P., Howard, A., Jung, T., Kelley, M., Large, W. G., Leboissetier, A., Lu, J., Madec, G., Marsland, S. J., Masina, S., Navarra, A., George Nurser, A. J., Pirani, A., y Mélia, D. S., Samuels, B. L., Scheinert, M., Sidorenko, D., Treguier, A.-M., Tsujino, H., Uotila, P., Valcke, S., Voldoire, A., and Wang, Q.: North Atlantic simulations in Coordinated Ocean-ice Reference Experiments phase II (COREII), Part I: Mean states, Ocean Modell., 73, 76-107, 2014.

Deal, C., Jin, M. B., Elliott, S., Hunke, E., Maltrud, M., and Jeffery, N.: Large-scale modeling of primary production and ice algal biomass within arctic sea ice in 1992, J. Geophys. Res.-Oceans, 116, C07004, doi:10.1029/2010jc006409, 2011.

de Boyer Montégut, C., Madec, G., Fischer, A. S., Lazar, A., and Iudicone, D.: Mixed layer depth over the global ocean: An examination of profile data and a profile-based climatology, J. Geophys. Res., 109, C12003, doi:10.1029/2004jc002378, 2004.

de Jong, J., Schoemann, V., Maricq, N., Mattielli, N., Langhorne, P., Haskell, T., and Tison, J.-L.: Iron in land-fast sea ice of McMurdo Sound derived from sediment resuspension and wind-blown dust attributes to primary productivity in the Ross Sea, Antarctica, 157, 24-40, 2013.

Ducklow, H. W., Schofield, O., Vernet, M., Stammerjohn, S., and Erickson, M.: Multiscale control of bacterial production by phytoplankton dynamics and sea ice along the western Antarctic Peninsula: A regional and decadal investigation, J. Mar. Syst., 98/99, 26-39, 2012.

Fitch, D. T. and Moore, J. K.: Wind speed influence on phytoplankton bloom dynamics in the southern ocean marginal ice zone, J. Geophys. Res.-Oceans, 112, C08006, doi:10.1029/2006jc004061, 2007.

Garcia , H. E., Locarnini, R. A., Boyer, T. P., and Antonov, J. I.: World Ocean Atlas 2005, Volume 4: Nutrients (phosphate, nitrate, silicate), edited by: Levitus, S., NOAA Atlas NESDIS 64, US Government Printing Office, Washington, DC, 396 pp., 2006.

Geider, R. J., MacIntyre, H. L., and Kana, T. M.: A Dynamic Regulatory Model of Phytoplanktonic Acclimation to Light, Nutrients, and Temperature, Limnol. Oceanogr., 43, 679-694, 1998.

Gent, P. R., Danabasoglu, G., Donner, L. J., Holland, M. M., Hunke, E. C., Jayne, S. R., Lawrence, D. M., Neale, R. B., Rasch, P. J., Vertenstein, M., Worley, P. H., Yang, Z. L., and Zhang, M. H.: The Community Climate System Model Version 4, J. Climate, 24, 4973-4991, 2011.
Grotti, M., Soggia, F., Ianni, C., and Frache, R.: Trace metals distributions in coastal sea ice of Terra Nova Bay, Ross Sea, Antarctica, Antarc. Sci., 17, 289-300, 2005.

Holland, M. M., Bitz, C. M., and Tremblay, B.: Future abrupt reductions in the summer Arctic sea ice, Geophys. Res. Lett., 33, L23503, doi:10.1029/2006g1028024, 2006.

Holland, M. M., Bailey, D. A., Briegleb, B. P., Light, B., and Hunke, E.: Improved Sea Ice Shortwave Radiation Physics in CCSM4: The Impact of Melt Ponds and Aerosols on Arctic Sea Ice, J. Climate, 25, 1413-1430, 2012.

Holland, P. R. and Kwok, R.: Wind-driven trends in Antarctic seaice drift, Nat. Geosci., 5, 872-875, 2012.

Hunke, E. C. and Lipscomb, W. H.: CICE: the Los Alamos Sea Ice Model Documentation and Software User's Manual Version 4.1 LA-CC-06-012, T-3 Fluid Dynamics Group, Los Alamos National Laboratory, 2010.

Jeffery, N., Hunke, E. C., and Elliott, S. M.: Modeling the transport of passive tracers in sea ice, J. Geophys. Res.-Oceans, 116, C07020, doi:10.1029/2010jc006527, 2011.

Jickells, T. D., An, Z. S., Andersen, K. K., Baker, A. R., Bergametti, G., Brooks, N., Cao, J. J., Boyd, P. W., Duce, R. A., Hunter, K. A., Kawahata, H., Kubilay, N., laRoche, J., Liss, P. S., Mahowald, N., Prospero, J. M., Ridgwell, A. J., Tegen, I., and Torres, R.: Global iron connections between desert dust, ocean biogeochemistry, and climate, Science, 308, 67-71, 2005.

Kalnay, E., Kanamitsu, M., Kistler, R., Collins, W., Deaven, D., Gandin, L., Iredell, M., Saha, S., White, G., Woollen, J., Zhu, Y., Chelliah, M., Ebisuzaki, W., Higgins, W., Janowiak, J., Mo, K. C., Ropelewski, C., Wang, J., Leetmaa, A., Reynolds, R., Jenne, R., and Joseph, D.: The NCEP/NCAR 40-year reanalysis project, Bull. Am. Meteorol. Soc., 77, 437-471, 1996.

Key, R. M., Kozyr, A., Sabine, C. L., Lee, K., Wanninkhof, R., Bullister, J. L., Feely, R. A., Millero, F. J., Mordy, C., and Peng, T. H.: A global ocean carbon climatology: Results from Global Data Analysis Project (GLODAP), Global Biogeochem. Cy., 18, GB4031, doi:10.1029/2004gb002247, 2004.

Klunder, M. B., Bauch, D., Laan, P., de Baar, H. J. W., van Heuven, S., and Ober, S.: Dissolved iron in the Arctic shelf seas and surface waters of the central Arctic Ocean: Impact of Arctic river water and ice-melt, J. Geophys. Res.-Oceans, 117, C01027, doi:10.1029/2011jc007133, 2012.

Kurtz, N. T. and Markus, T.: Satellite observations of Antarctic sea ice thickness and volume, J. Geophys. Res.-Oceans, 117 , C08025, doi:10.1029/2012jc008141, 2012.

Kwok, R., Cunningham, G. F., Wensnahan, M., Rigor, I., Zwally, H. J., and Yi, D.: Thinning and volume loss of the Arctic Ocean sea ice cover: 2003-2008, J. Geophys. Res.-Oceans, 114, C07005, 10.1029/2009jc005312, 2009.

Lancelot, C., de Montety, A., Goosse, H., Becquevort, S., Schoemann, V., Pasquer, B., and Vancoppenolle, M.: Spatial distribution of the iron supply to phytoplankton in the Southern Ocean: a model study, Biogeosciences, 6, 2861-2878, doi:10.5194/bg-62861-2009, 2009.

Lannuzel, D., Schoemann, V., de Jong, J., Tison, J. L., and Chou, L.: Distribution and biogeochemical behaviour of iron in the East Antarctic sea ice, Mar. Chem., 106, 18-32, 2007.

Lannuzel, D., Schoemann, V., de Jong, J., Chou, L., Delille, B., Becquevort, S., and Tison, J. L.: Iron study during a time series in the western Weddell pack ice, Mar. Chem., 108, 85-95, 2008. 
Lannuzel, D., Schoemann, V., de Jong, J., Pasquer, B., van der Merwe, P., Masson, F., Tison, J. L., and Bowie, A.: Distribution of dissolved iron in Antarctic sea ice: Spatial, seasonal, and inter-annual variability, J. Geophys. Res.-Biogeosciences , 115, G03022, doi:10.1029/2009jg001031, 2010.

Lannuzel, D., Bowie, A. R., van der Merwe, P. C., Townsend, A. T., and Schoemann, V.: Distribution of dissolved and particulate metals in Antarctic sea ice, Mar. Chem., 124, 134-146, 2011.

Lannuzel, D., Schoemann, V., Dumont, I., Content, M., de Jong, J., Tison, J.-L., Delille, B., and Becquevort, S.: Effect of melting Antarctic sea ice on the fate of microbial communities studied in microcosms, Polar Biol., 36, 1483-1497, 2013.

Lannuzel, D., van der Merwe, P. C., Townsend, A. T., and Bowie, A. R.: Size fractionation of iron, manganese and aluminium in Antarctic fast ice reveals a lithogenic origin and low iron solubility, Mar. Chem., 161, 47-56, 2014.

Large, W. G. and Yeager, S. G.: The global climatology of an interannually varying air-sea flux data set, Clim. Dynam., 33, 341364, 2009

Lee, S. H., Kim, B. K., Yun, M. S., Joo, H., Yang, E. J., Kim, Y. N., Shin, H. C., and Lee, S.: Spatial distribution of phytoplankton productivity in the Amundsen Sea, Antarctica, Polar Biol., 35, 1721-1733, 2012.

Lin, H., Rauschenberg, S., Hexel, C. R., Shaw, T. J., and Twining, B. S.: Free-drifting icebergs as sources of iron to the Weddell Sea, Deep-Sea Res. Pt. I, 58, 1392-1406, 2011.

Maenhaut, W., Ducastel, G., Leck, C., Nilsson, E. D., and Heintzenberg, J.: Multi-elemental composition and sources of the high Arctic atmospheric aerosol during summer and autumn, Tellus B, 48, 300-321, 1996.

Mahowald, N. M., Baker, A. R., Bergametti, G., Brooks, N., Duce, R. A., Jickells, T. D., Kubilay, N., Prospero, J. M., and Tegen, I.: Atmospheric global dust cycle and iron inputs to the ocean, Global Biogeochem. Cy., 19, Gb4025, doi:10.1029/2004gb002402, 2005

Maslanik, J. A., Fowler, C., Stroeve, J., Drobot, S., Zwally, J., Yi, D., and Emery, W.: A younger, thinner Arctic ice cover: Increased potential for rapid, extensive sea-ice loss, Geophys. Res. Lett., 34, L24501, doi:10.1029/2007g1032043, 2007.

Measures, C. I.: The role of entrained sediments in sea ice in the distribution of aluminium and iron in the surface waters of the Arctic Ocean, Mar. Chem., 68, 59-70, 1999.

Moore, J. K. and Braucher, O.: Sedimentary and mineral dust sources of dissolved iron to the world ocean, Biogeosciences, 5, 631-656, doi:10.5194/bg-5-631-2008, 2008.

Moore, J. K., Doney, S. C., Kleypas, J. A., Glover, D. M., and Fung, I. Y.: An intermediate complexity marine ecosystem model for the global domain, Deep-Sea Res. Part II, 49, 403-462, 2002.

Moore, J. K., Doney, S. C., and Lindsay, K.: Upper ocean ecosystem dynamics and iron cycling in a global threedimensional model, Global Biogeochem. Cy., 18, GB4028, doi:10.1029/2004gb002220, 2004

Moore, J. K., Lindsay, K., Doney, S. C., Long, M. C., and Misumi, K.: Marine Ecosystem Dynamics and Biogeochemical Cycling in the Community Earth System Model [CESM1(BGC)]: Comparison of the 1990s with the 2090s under the RCP4.5 and RCP8.5 Scenarios, J. Climate, 26, 9291-9312, 2013.

Nakayama, Y., Fujita, S., Kuma, K., and Shimada, K.: Iron and humic-type fluorescent dissolved organic matter in the Chukchi
Sea and Canada Basin of the western Arctic Ocean, J. Geophys. Res.-Oceans, 116, C07031, doi:10.1029/2010jc006779, 2011.

Nghiem, S. V., Rigor, I. G., Perovich, D. K., Clemente-Colon, P., Weatherly, J. W., and Neumann, G.: Rapid reduction of Arctic perennial sea ice, Geophys. Res. Lett., 34, L19504, doi:10.1029/2007g1031138, 2007.

Nishimura, S., Kuma, K., Ishikawa, S., Omata, A., and Saitoh, S.: Iron, nutrients, and humic-type fluorescent dissolved organic matter in the northern Bering Sea shelf, Bering Strait, and Chukchi Sea, J. Geophys. Res.-Oceans, 117, C02025, doi:10.1029/2011jc007355, 2012.

Nurnberg, D., Wollenburg, I., Dethleff, D., Eicken, H., Kassens, H., Letzig, T., Reimnitz, E., and Thiede, J.: Sediments in Arctic sea ice: Implications for entrainment, transport and release, Mar. Geol., 119, 185-214, 1994.

Oza, S. R., Singh, R. K. K., Srivastava, A., Dash, M. K., Das, I. M. L., and Vyas, N. K.: Inter-annual variations observed in spring and summer Antarctic sea ice extent in recent decade, Mausam, 62, 633-640, 2011.

Pabi, S., van Dijken, G. L., and Arrigo, K. R.: Primary production in the Arctic Ocean, 1998-2006, J. Geophys. Res.-Oceans, 113, C08005, doi:10.1029/2007jc004578, 2008.

Parkinson, C. L. and Cavalieri, D. J.: Antarctic sea ice variability and trends, 1979-2010, Cryosphere, 6, 871-880, 2012.

Planquette, H., Sherrell, R. M., Stammerjohn, S., and Field, M. P.: Particulate iron delivery to the water column of the Amundsen Sea, Antarctica, Mar. Chem., 153, 15-30, 2013.

Rothrock, D. A., Yu, Y., and Maykut, G. A.: Thinning of the Arctic sea-ice cover, Geophys. Res. Lett., 26, 3469-3472, 1999.

Sedwick, P. N. and DiTullio, G. R.: Regulation of algal blooms in Antarctic shelf waters by the release of iron from melting sea ice, Geophys. Res. Lett., 24, 2515-2518, 1997.

Serreze, M. C., Holland, M. M., and Stroeve, J.: Perspectives on the Arctic's shrinking sea-ice cover, Science, 315, 1533-1536, 2007.

Shaw, T. J., Raiswell, R., Hexel, C. R., Vu, H. P., Moore, W. S., Dudgeon, R., and Smith, K. L.: Input, composition, and potential impact of terrigenous material from free-drifting icebergs in the Weddell Sea, Deep-Sea Res. Pt. I, 58, 1376-1383, 2011.

Smith, K. L., Robison, B. H., Helly, J. J., Kaufmann, R. S., Ruhl, H. A., Shaw, T. J., Twining, B. S., and Vernet, M.: Free-drifting icebergs: Hot spots of chemical and biological enrichment in the Weddell Sea, Science, 317, 478-482, 2007.

Smith, R. D., Jones, P., Briegleb, B. P., Bryan, F., Danabasoglu, G., Dennis, J., Dukowicz, J., Eden, C., Fox-Kemper, B., Gent, P., Hecht, M., Jayne, S., Jochum, M., Large, W., Lindsay, K., Maltrud, M., Norton, N., Peacock, S., Vertenstein, M., and Yeager, S.: The Parallel Ocean Program (POP) reference manual, ocean component of the Community Climate System Model (CCSM), Los Alamos National Laboratory Tech. Rep. LAUR-10-01853, 141 pp., 2010.

Smith, W. O. and Nelson, D. M.: phytoplankton bloom produced by a receding ice edge in the ross sea - spatial coherence with the density field, Science, 227, 163-166, 1985.

Stabeno, P., Napp, J., Mordy, C., and Whitledge, T.: Factors influencing physical structure and lower trophic levels of the eastern Bering Sea shelf in 2005: Sea ice, tides and winds, Prog. Oceanogr., 85, 180-196, 2010.

Stroeve, J. C., Kattsov, V., Barrett, A., Serreze, M., Pavlova, T., Holland, M., and Meier, W. N.: Trends in Arctic sea ice extent 
from CMIP5, CMIP3 and observations, Geophys. Res. Lett., 39, L16502, doi:10.1029/2012g1052676, 2012.

Tagliabue, A. and Arrigo, K. R.: Processes governing the supply of iron to phytoplankton in stratified seas, J. Geophys. Res., 111, C06019, doi:10.1029/2005jc003363, 2006.

Tagliabue, A., Bopp, L., Dutay, J.-C., Bowie, A. R., Chever, F., Jean-Baptiste, P., Bucciarelli, E., Lannuzel, D., Remenyi, T., Sarthou, G., Aumont, O., Gehlen, M., and Jeandel, C.: Hydrothermal contribution to the oceanic dissolved iron inventory, Nature Geosci., 3, 252-256, 2010.

Tagliabue, A., Mtshali, T., Aumont, O., Bowie, A. R., Klunder, M. B., Roychoudhury, A. N., and Swart, S.: A global compilation of dissolved iron measurements: focus on distributions and processes in the Southern Ocean, Biogeosciences, 9, 2333-2349, doi:10.5194/bg-9-2333-2012, 2012.

Tagliabue, A., Sallée, J.-B., Bowie, A. R. , Lévy, M., Swart, S., and Boyd, P. W. : Surface-water iron supplies in the Southern Ocean sustained by deep winter mixing, Nature Geosci., 7, 314-320, 2014.

Taylor, M. H., Losch, M., and Bracher, A.: On the drivers of phytoplankton blooms in the Antarctic marginal ice zone: A modeling approach, J. Geophys. Res.-Oceans, 118, 63-75, 2013.

Thomas, D. N. and Dieckmann, G. S.: Ocean science - Antarctic Sea ice - a habitat for extremophites, Science, 295, 641-644, 2002.

Tovar-Sanchez, A., Duarte, C. M., Alonso, J. C., Lacorte, S., Tauler, R., and Galban-Malagon, C.: Impacts of metals and nutrients released from melting multiyear Arctic sea ice, J. Geophys. Res.Oceans, 115, C07003, doi:10.1029/2009jc005685, 2010.
US Department of Commerce: 2-minute global gridded relief data. National Oceanographic and Atmospheric Administration, National Geophysical Data Center, 2006.

van der Merwe, P., Lannuzel, D., Nichols, C. A. M., Meiners, K., Heil, P., Norman, L., Thomas, D. N., and Bowie, A. R.: Biogeochemical observations during the winter-spring transition in East Antarctic sea ice: Evidence of iron and exopolysaccharide controls, Mar. Chem., 115, 163-175, 2009.

van der Merwe, P., Lannuzel, D., Bowie, A. R., and Meiners, K. M.: High temporal resolution observations of spring fast ice melt and seawater iron enrichment in East Antarctica, J. Geophys. Res.-Biogeosciences, 116, G03017, doi:10.1029/2010jg001628, 2011a.

van der Merwe, P., Lannuzel, D., Bowie, A. R., Nichols, C. A. M., and Meiners, K. M.: Iron fractionation in pack and fast ice in East Antarctica: Temporal decoupling between the release of dissolved and particulate iron during spring melt, Deep-Sea Res. Pt. I, 58, 1222-1236, 2011b.

Vancoppenolle, M., Goosse, H., de Montety, A., Fichefet, T., Tremblay, B., and Tison, J. L.: Modeling brine and nutrient dynamics in Antarctic sea ice: The case of dissolved silica, J. Geophys. Res.-Oceans, 115, C02005, doi:10.1029/2009jc005369, 2010.

Wang, S. and Moore, J. K.: Incorporating Phaeocystis into a Southern Ocean ecosystem model, J. Geophys. Res., 116, C01019, doi:10.1029/2009jc005817, 2011. 